\title{
Chapter 18 \\ Technologies for Maize, Wheat, Rice and Pulses in Marginal Districts of Bihar and Odisha
}

\author{
P.K. Joshi, Devesh Roy, Vinay Sonkar, and Gaurav Tripathi
}

\begin{abstract}
This chapter looks at potential technologies for marginal districts in two of the most backward states in India - Bihar and Odisha. Based on technological performance, we identified the marginal districts for four principal crops, i.e. rice, wheat, maize and pulses, and assessed the potential of the technologies in terms of their agro-ecological suitability, as well as the complementary inputs required for success. Using a primary survey, we gauge the real opportunities and constraints for technology adoption directly from the farmers, including their aspirations about crop choices and the technologies that exist to grow them. Maize and pulses turn out to be crops that farmers currently aspire to get into. Also, data distinctly reveals, in some cases, the disconnect between perceived potential of the technology among experts and the valuation of the same by likely adopters.
\end{abstract}

Keywords Marginality • Technology adoption • Aspirations • Perceptions • India

\section{Introduction}

This chapter summarizes the current state of agricultural productivity and the potential of different technologies in two of the most economically backward states in India, Bihar and Odisha, for their principal crops, rice, wheat, maize and pulses. Focusing on marginal districts in the two states, the paper assesses the suitability of different technologies to uplift the areas (districts) out of their current low level equilibrium (in terms of production performance) and thereby raise the standards of

P.K. Joshi $(\bowtie) \cdot$ D. Roy

International Food Policy Research Institute (IFPRI), Washington, DC, USA

e-mail: p.joshi@cgiar.org; d.roy@cgiar.org

V. Sonkar • G. Tripathi

International Food Policy Research Institute (IFPRI), New Delhi, India

e-mail: V.K.Sonkar@cgiar.org; g.tripathi@cgiar.org 
living. ${ }^{1}$ The marginal (backward) districts for these crops are identified based on current yield and its performance over time. Subsequently, the choice of technologies for marginal areas for each case is analyzed ex ante. In this approach, the potential is assessed under conditions in which a given technology might not be widely adopted currently but has a comparatively high potential to deliver upon adoption. $^{2}$

The short listing of technologies for these crops has been done based on a clearing house approach in which, in consultation with different stakeholders, the potent technologies for districts have been chosen. Two multi-stakeholder workshops in Bihar and Odisha for identifying innovative technologies with input from farmers, the private sector and NGOs, natural resource management experts and specialists in market-linkages resulted in the short-listed technologies which have already been field tested but have yet to be adopted at all or adopted on a large scale.

Following this, through a structured survey of the households, we examine the reasons behind slow or poor adoption of available technological innovations. We look at the profile of the identified technologies in terms of their uptake over time and try to assess the role of complementary inputs that affect the feasibility for the respective areas, as well as the prospects for adopters of technology to multiply.

The paper is organized as follows. Section "Identifying Marginal Areas (Districts) in Bihar and Odisha" presents the scheme for identification of the marginal districts in the two states. The fixing of marginality is crop specific. After fixing marginality in section "Technologies for Marginal Districts in Bihar and Odisha: Findings from Multi-Stakeholder Consultations", the next section looks at the potent technologies for these areas. Subsequently, based on field surveys, we gauge the suitability of the identified technology for the marginal areas in section "Findings from the Farmer Survey". Section "Awareness of Technologies and Their Adoption in Bihar and Odisha" summarizes the findings from the survey. Section "Regression Analysis for Awareness and Adoption of Technologies in Rice, Wheat and Maize in Bihar and Odisha" presents some illustrative regression results for wheat, rice, maize and pulses. Section "Conclusions and Policy Recommendations" concludes.

\footnotetext{
${ }^{1}$ Usually, a combination of indicators is used in multi-dimensional criteria for assessing marginality. In this paper, we reduce the dimensionality problem in identification of marginal areas to just two. In particular, we look at the dynamic behavior of yields in combination with the current relative yield positions to fix marginality. Thus, the two indicators are both related to yield behavior. The first one is increasing or decreasing yields over time at different absolute levels and the second one comprises relative yield positions of preselected crops grown in the district. The filter for marginal districts is based on the intersection of these two indicators. A district with falling yields and positioned in the lowest quartile of yield distribution, for example, would clearly qualify as a marginal district in what we call Tier 1. Other levels of these two indicators determine the tier levels for marginal districts. A moderately falling yield over time with a current state of first or second quartile of yield distribution may comprise Tier 2 marginal districts and so on.

${ }^{2}$ Wheat is cropped in a very small area in Odisha. Hence, we do not study the case of wheat in that state.
} 


\section{Identifying Marginal Areas (Districts) in Bihar and Odisha}

The eastern part of India where Bihar and Odisha are situated is rich in natural resources, such as water, year-round bright sunlight, fertile soil and forest, and mineral reserves. However, eastern India has not been able to capitalize upon its vast resource pool owing to different factors, such as underdeveloped basic infrastructure (like roads, power and markets), concentration of the poor population with high density in most parts, weak institutions (such as credit, insurance, education and extension) and weak governance. These bottlenecks have rendered the region unattractive for investment.

Among states, Bihar and Odisha lie at the bottom of the scale for various socioeconomic indicators. The agriculture sector in these states represents their lifeline; $73.6 \%$ and $61.8 \%$ of the working population in Bihar and Odisha, respectively, draw their livelihood from agriculture vis-à-vis $54.6 \%$ throughout all of India. The percentages of the working population mainly/exclusively dependent on agriculture in Bihar and Odisha are $43.1 \%$ and $32.5 \%$, respectively (MHA 2011). However, the share of agriculture and the allied sector in Gross Domestic Product (GDP) of Bihar and Odisha was just $23.0 \%$ and $16.4 \%$, respectively, in 2011-2012. The annual growth rates of agriculture and the allied sector in Bihar (3.9\%) and Odisha $(3.0 \%)$ were lower than the all India average (8.5\%) during the period 2004-2005 to 2011-2012. In spite of relatively better growth rates exhibited by the industry and service sectors over the last decade (albeit with a very low base), these states have not made significant headway in poverty reduction during 2011-2012, with $33.8 \%$ and $32.6 \%$ of the population in Bihar and Odisha respectively still below the poverty line (Planning Commission 2013).

The slow agricultural growth rate, along with its low share in state GDP, cannot raise the standard of living of a large population since inadequate infrastructure, particularly inadequacy of power, seriously limits the growth of industries. Hence, a structural shift in employment from low income farming to high value industrial and service sectors is not expected, at least in the medium term (GoI 2008). Therefore, to reduce poverty and elevate the marginal areas effectively, it is imperative to bring about sustained growth in the agriculture and allied sectors in Bihar and Odisha.

Moreover, in both states, there exists significant regional disparity. To further the discussion, we first present the criteria for the identification of marginal districts in the two states. We consider districts to be marginal based on two factors, i.e., dynamic changes in yield and the current levels of yield. Specifically, we take cropspecific marginal areas to be the ones where yields have been declining over time (or rising comparatively slowly) and are currently at levels that are subpar relative to the other districts in the state. The current yields are clubbed into four quartiles of the distribution over districts with yields in lower quartiles taken to be subpar. A district, for example, that had yield falling significantly (such as in double digit percentages, known as a double dip) for a crop and settling into the lowest quartile of the yield distribution would clearly be among the marginal districts. In more 
intermediate cases, it is the relative current levels of yield and relative changes in yields over time that affix the marginality of the districts.

For illustration, Fig. 18.1 presents the dynamics of rice, maize and pulse yields in Odisha. The figure plots the average yields (averaged over 6 years) of the three crops at two points in time across districts in Odisha. A few important points emerge from this figure. First, there is significant inter- district variation in the three cases. More importantly, there is distinctive variation in yields over time. ${ }^{3}$

Tables 18.1 (on cereals) and 18.2 (on pulses) present the status of different districts in Odisha in terms of their location in the space comprising dynamic behavior of yields of these crops and their current status in terms of relative yields. The columns present double or single dip decreases and single, double or triple digit increases in yields for the districts in the case of rice, pulses and maize, respectively. ${ }^{4}$ The numbers next to the districts represent the quartile to which the yield of the district belongs in the yield distribution. A number 0 next to the district represents the case of lowest yield. In maize, for instance, Puri and Jagatsinghpur, with the lowest yields, have been put in the 0 category, while for rice, the lowest is Sundargarh.

Especially salient are the districts which, even after double crest increases in yields, continue to languish with their current yields in the lowest quartile. Districts such as Angul for maize and Malkangiri for rice fall into this category. Similarly, districts like Deogarh, Bolangir, Kendrapara, Angul and Keonjhar in rice, in spite of experiencing yield increases, still fall in the bottom quartile of rice yield distribution. In the case of maize, the districts that have experienced yield increases but still are in the lowest quartile of yields across districts comprise Bolangir, Boudh, Angul, Jajpur, Keonjhar, Mayurbhanj, Khurda and Balasore (Table 18.1). We select a few districts from this set of marginal areas for primary data collection to analyze the awareness about and adoption of shortlisted technologies. The districts selected in Odisha are Angul, Deogarh and Boudh, because they cover marginal areas in all of the three crops.

Analyses similar to Odisha were conducted in Bihar as well to identify marginal districts. The only difference was that, in Bihar, wheat was also included, being an important cereal crop there. Using same method as for Odisha in choosing districts for primary survey, the districts in Bihar selected for primary surveys are Araria, Muzaffarpur and East Champaran.

Though the criteria for choosing marginal districts is technology-centric, it turns out that, with principal crops, on average, the shortlisted districts are congruent with the list of poor districts in terms of expenditures based on the national sample survey in India. The list of marginal districts also overlaps significantly with the set

\footnotetext{
${ }^{3}$ Comparing rice and maize, both within as well as across, variation in Odisha is far more pronounced in the latter. This might be due to greater spatial differences in adoption of technology in maize than in rice.

${ }^{4}$ Single dip, double dip, single crest, double crest and triple crest imply single digit percentage drops, double digit percentage drops, single digit percentage increases, and double and triple digit percentage increases in yields over time.
} 

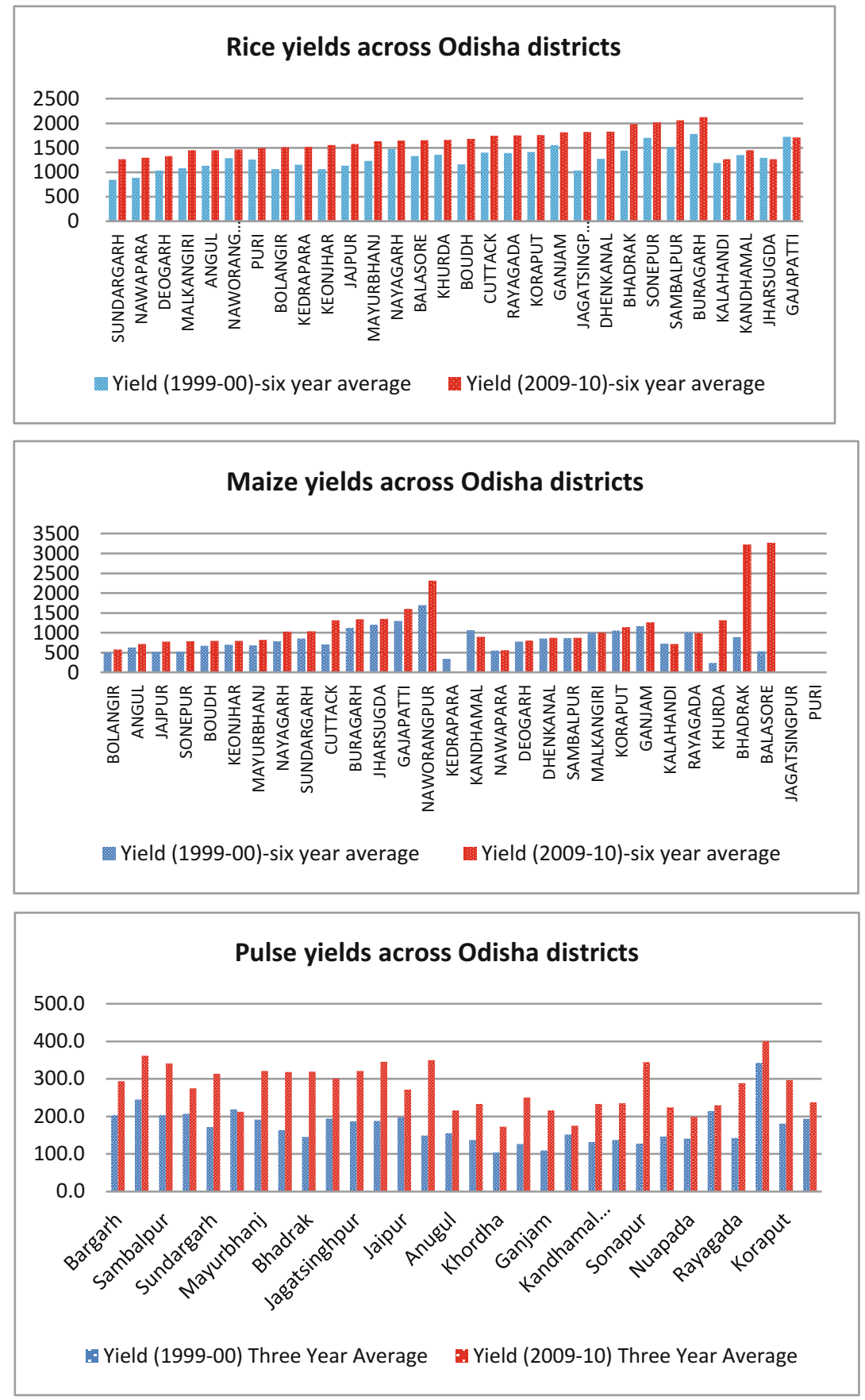

Fig. 18.1 Dynamics of yields of principal crops across districts in Odisha 


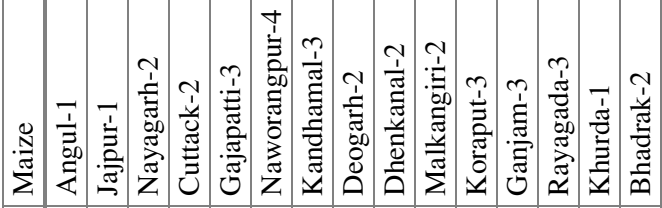

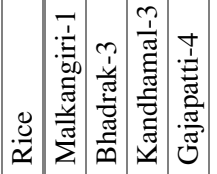

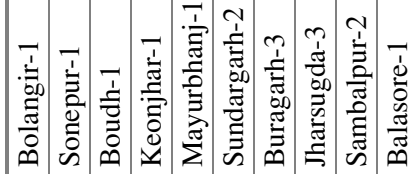

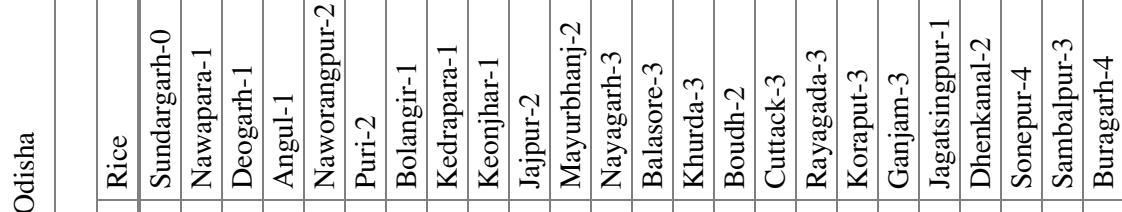

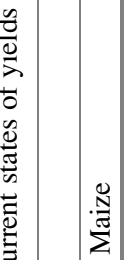

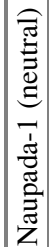

$\frac{8}{2}$

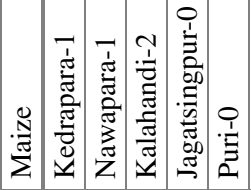

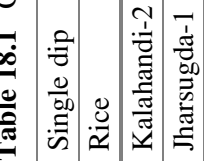


Table 18.2 Dynamics of yields and current state of pulses in Odisha

\begin{tabular}{l|l|l|l}
\hline Single dip & Double crest & Double crest & Triple crest \\
\hline Keonjhar-0 & Gajapati-1 & Mayurbhanj-3 & Rayagada-3 \\
\hline & Nabarangapur-4 & Sambalpur-4 & Bhadrak-3 \\
\hline & Malkangiri-2 & Nayagarh-2 & Dhenkanal-4 \\
\hline & Debagarh-3 & Baudh-2 & Sonapur-4 \\
\hline & Jaipur-2 & Jagatsinghpur-2 & \\
\hline & Anugul-1 & Kandhamal Phoolbani-2 & \\
\hline & Nuapada-1 & Sundargarh-3 & \\
\hline & Bargarh-3 & Cuttack-4 & \\
\hline & Jharsuguda-4 & Baleshwar-3 & \\
\hline & Balangir-1 & Ganjam-1 & \\
\hline & Kendrapara-3 & Puri-2 & \\
\hline & Koraput-3 & & \\
\hline & Khordha-1 & &
\end{tabular}

of backward districts marked by the planning commission. Figures 18.2 and 18.3 present maps of districts in the two states in terms of poverty levels based on expenditure data from national sample survey data in 2006.

\section{Technologies for Marginal Districts in Bihar and Odisha: Findings from Multi-Stakeholder Consultations}

With the aim of validating identification of marginal districts, and of potent technologies for such areas, two workshops were organized in Bihar and Odisha, respectively. The workshops included experts from agricultural research institutions/universities, government officials, private sector representatives, members of non-governmental organizations, farmers and other relevant organizations, e.g., from renewable energy sources in agriculture.

The workshops followed a clearing house model in which the identification of relevant districts was put to participants and a commonly agreed-upon list of marginal areas was prepared for each crop. In addition, there were deliberations on crops and activities in the two states in terms of technologies with the potential to improve outcomes. Based on secondary data, workshop findings and interactions with scientists and technology experts, suitable technologies were identified for raising productivity in the marginal districts.

The technological solutions presented below cover a spectrum relating to improved/hybrid seed varieties, specific to particular agro-climatic ecosystems; cultivation processes; mechanization; irrigation; training and extension; and market linkages, among others. Most of these technologies have been tested in the field, both by research institutions and sometimes by innovative/progressive farmers. However, they have yet to be adopted or adopted on a large scale in the marginal 


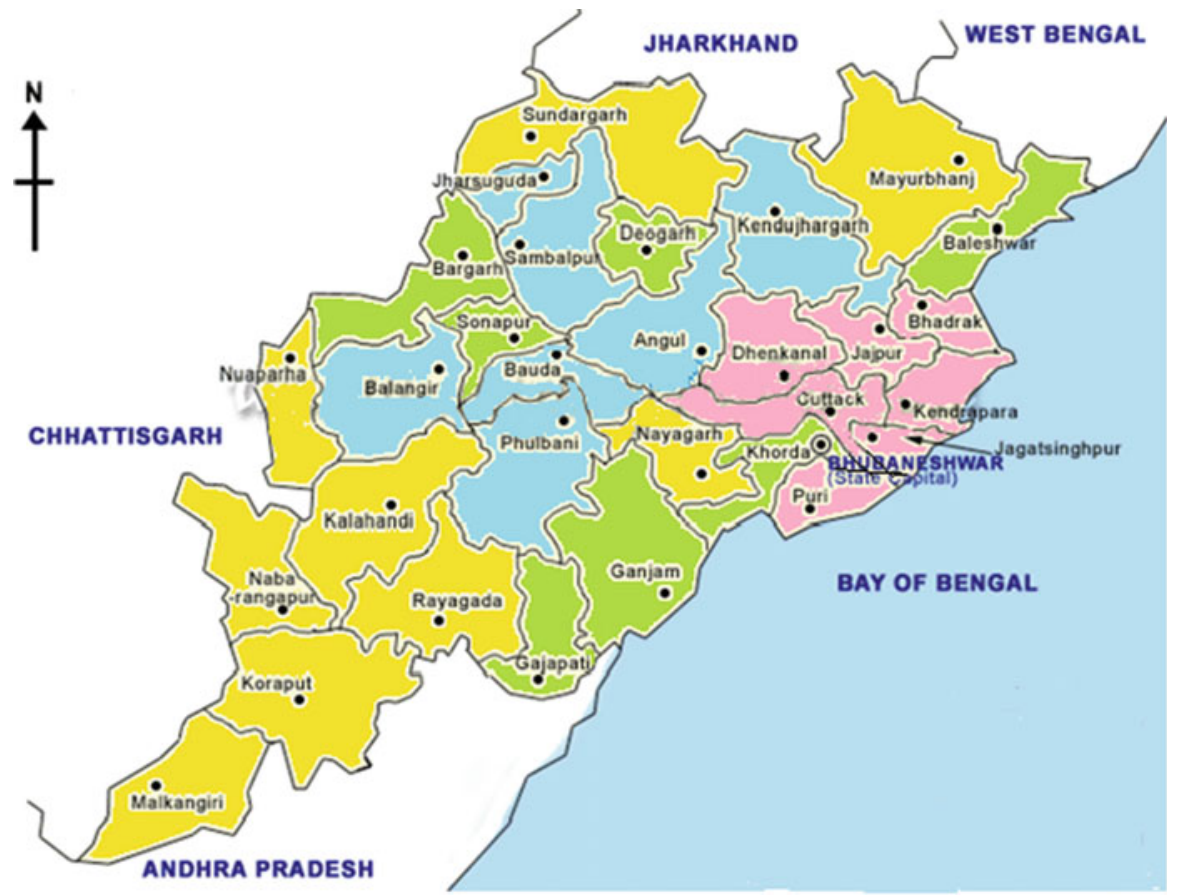

Fig. 18.3 Head count ratio Odisha

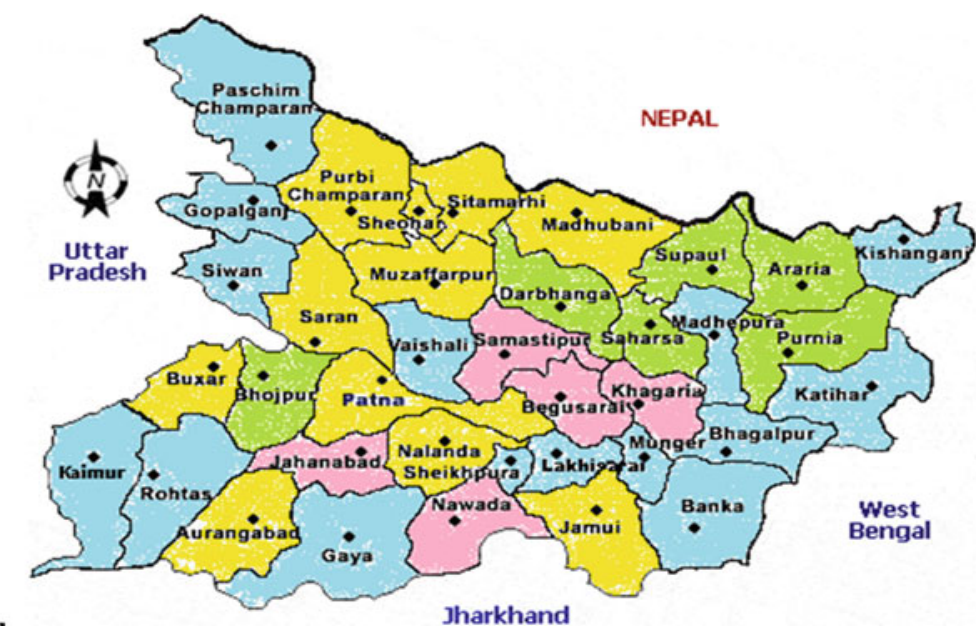

Poverty-levels

Jharkhand
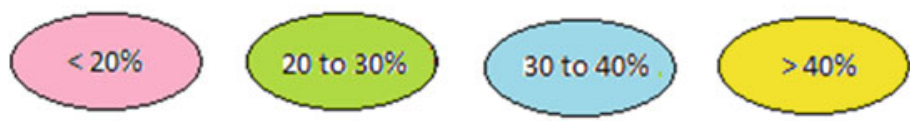

Fig. 18.2 Headcount ratios across districts in Bihar (2006) based on NSS data 
districts. We thus examine the reasons behind slow or poor adoption of technological innovations through a household survey.

\section{Technologies for Marginal Districts}

Below, we present the list of technologies identified as having high potential for different crops for the marginal districts in Bihar and Odisha. Subsequently, we focus on the state of awareness of technologies and their adoption based on primary surveys in the two states.

\section{Rice}

The technologies in rice with underexploited potential in the marginal districts are as follows:

1. Varietal substitution towards (climatic) stress-tolerant, high-yielding varieties developed and tested for specific agro-climatic ecosystems. Some marginal districts lie in these ecosystems and adequate varieties need to be promoted for these areas. The rice cultivars that are high yielding and tolerant to climatic stress (including drought and flood) are available to try in the marginal districts of the two states. For example, the Swarna Sub 1 and Varshadhan rice varieties give high yields under flood conditions, while Sahbhagidhan cultivar (IR 7437170-1-1) is drought-tolerant (see Yamano et al. 2013; Reddy et al. 2009). However, ready availability of the right seed cultivars is an issue.

2. Mechanized Direct Seeded Rice (DSR) technology for rice-cultivation among small and marginal farmers. This technology saves on cultivation costs by conserving labor and water for irrigation; it also enables timely sowing that helps achieve higher yields for rice, as well as for the succeeding winter crop (wheat) (see Pathak et al. 2011). The crop matures earlier than the traditional practice by 7-10 days. Begusarai is the most marginal rice district in Bihar (with the lowest yields currently across districts). It has started to see some success with DSR. The adoption and spread of this technology needs to be initiated and scaled up in other marginal areas as well. In Odisha, the mechanized DSR is a new phenomenon; its introduction into the state dates to 2009-2010. It has so far not been widespread. Odisha is predominantly engaged in manual DSR - $80 \%$ of the rice cultivation area was under manual DSR in 1990.

3. Mechanization of agriculture promoted by custom hiring centers-Specific promotion of the self-propelled paddy trans-planter machine- This technology has been estimated to increase yields by an estimated $20 \%$ through increased operational efficiency and facilitating uniform and optimum plant population. It is estimated to reduce seed-requirement by as much as $40 \%$ while saving on costs of nursery preparation and transplanting. Mechanization through 
establishment of custom hiring centers and machinery hubs could be tried through the system of Krishi Vigyan Kendras (Agriculture Science Centers); with the facility of training the youths, it can facilitate mechanization of agriculture for small and marginal farmers (Srinivasarao et al. 2013).

Timely transplanting of rice is facilitated through the use of the self-propelled paddy trans planter, while also reducing costs of labor, fertilizer, seed and irrigation, as well as ensuring uniform spacing and optimum plant density. Post-2004, the mechanization efforts in Bihar have met with some success; Odisha has to cover more ground in promoting mechanization. Mainstreaming custom hiring centers would be an important contributor to improving the outcomes in the marginalized districts. There are possible synergies with other forms of mechanization as well, such as the power-tiller, the pedal thresher and the paddy reaper. The economies of scope should be exploited among the different forms of mechanization.

4. Use of integrated nutrient management, involving use of both organic and inorganic fertilizers can result in superior yields and the achievement of better 'nutrient-use-efficiency', but requires many complementary inputs. The System of Rice Intensification (SRI), for example, in conjunction with organic treatment can, in principle, give significantly higher yield and superior nutrient-use efficiency to rice (see Prasad 2006).

\section{Maize}

In maize, the salient technology is the adoption of hybrid varieties, most importantly the single cross hybrids ( $\mathrm{SCH})$ that have become widespread in Bihar. The spread of hybrid maize is far more muted in Odisha. Within Bihar as well, hybrid varieties of maize have largely bypassed the marginal districts. Also, there has been much lower adoption of hybrid maize in the rainy season because of flooding issues. Bihar experienced severe floods in 2004-2005, 2007-2008 and 2008-2009 that were most intense in the northern and eastern districts. Waterlogging affects crop yields in an area of about 0.63 million ha (6.7 \% of the total) (Chowdhary et al. 2008).

In some of the marginal districts, the moisture created under good rainfall, particularly in northern Bihar, provides for maize sown in the winter and summer seasons. Maize is less water intensive than rice and wheat. Hence, it is able to overcome the irrigation deficit during the winter and summer seasons arising from the high costs and limited availability of diesel for energizing pumps. However, there is also a greater prevalence of pests, diseases and weeds in the rainy season.

Because of these factors, the adoption pattern of hybrid maize in Bihar is mixed, with high uptake in the winter/spring seasons and relatively lower adoption in the rainy (Kharif) season. The next frontier for maize might be extending its success to those areas lagging behind and expanding the seasonal coverage of hybrid seeds by expanding hybrid maize production during the rainy season. In truth, over the last two decades, the area under maize cultivation in Bihar declined by $13.7 \%$ during 
the Kharif season, but it increased by over $29 \%$ and $58 \%$, respectively, in the Rabi and spring seasons.

Furthermore, in the marginal maize districts, farmers could be advised to grow maize on raised beds/ridges to reduce the risk of floods/excess water, which will in turn encourage adoption of hybrids during the rainy season as well. Some of the marginal districts for maize lie in low land areas where this technology should be promoted.

In general, there is a lack of timely availability of hybrid seeds and other agricultural inputs for farmers, along with the usual demand supply gap and lack of timely availability in the rainy season. This can be addressed through an increase in seed production and by strengthening the seed supply chains. Adequate attention is warranted from the private sector during the rainy season, similar to its role in the winter/spring seasons in heralding the hybrid maize revolution in the rainy season. Marginal districts have the potential to become the maize seed hubs of east-India owing to the favorable agro-climatic conditions prevailing mainly in the winter season, along with their fertile and plain land. Marginal districts can enjoy great commercial benefit from sales/export of seed, grain and technology for maize.

\section{Wheat}

The wheat technologies (broadly defined) identified for the marginal districts are:

1. Surface seeding technique for rice-wheat systems: This involves the broadcast of wheat-seeds in standing rice crops, under a condition of excess moisture (low land moist field) 15-25 days before the paddy-harvest. It helps avoid delay in wheat sowing, while also saving on tillage cost. Due to timely planting, higher yields are achieved. Further, it saves water in amounts from $35 \%$ to $40 \%$.

2. Zero tillage wheat with Resource Conserving Technologies (RCTs): This involves different sowing practices (like equal row, paired row and control traffic). It can be done through suitable zero till (ZT) drills, double disc planters, multi-crop planters and rotary disc drills in rice residue. Immediately after the rice harvest, zero till wheat is sown through use of a ZT drill, which advances the sowing by 15-20 days, thereby helping escape the terminal heat stress prevalent in many marginal districts in Bihar and Odisha. It is estimated to save as much as Rs. 2500/ha in tillage, $20 \%$ in seed, and $20 \%$ in first irrigation, besides an additional yield gain of about 1.0 tons/ha (based on focus group discussions and expert elicitation).

3. Laser land leveling ( $L L L)$ : This saves irrigation water, increases cultivable area by $3-5 \%$, improves crop establishment, improves uniformity of crop maturity, increases water application efficiency up to $50 \%$, increases crop yield by $15 \%$, and improves weed control efficiency. The cost of LLL on average is Rs. 400/h and the average cost of leveling is found to be in the range of Rs. 5000-9500/ha. Like other costly machinery, this will also require a system of custom hiring to increase adoption among small and marginal farmers. LLL is thus a resource- 
conserving technology. In surface-irrigated rice-wheat systems, 10-25\% of irrigation water is lost because of poor management and uneven fields. Uneven fields also lead to inefficient use of fertilizers and chemicals, increased biotic and abiotic stress, and lower yields (Lybbert et al. 2013).

\section{Pulses}

Overall, pulses have been confined to marginal environments, as comparatively resource-rich farmers have tended to prefer crops like paddy or wheat, or cash crops like cotton. Studies have attributed the low yield per hectare to various factors, mainly a lack of high-yielding and short-duration varieties and competition with other crops. Inadequate irrigation, cultivation in inferior lands, absence of fertilizer use, frequent attack by pests and diseases, dearth of extension services and poor infrastructure, and slow transfer of technology have also disadvantaged the pulse sector in states like Bihar and Odisha (Banerjee and Palke 2010). However, pulses have been coming up in Odisha since 2000, while they have continued their slide in Bihar, implying a dire need to bring in technology for pulses in that state.

In the two states, cereals continue to dominate among crops. Not much change is reflected in the case of pulses and oilseeds. Their contribution to the crop-sector fluctuated roughly 5-6\% between 2001 and 2008. In pulses, only seven districts in Bihar showed significant growth in production in the last decade. The prominent marginal districts in Bihar for pulses are Madhubani, Darbhanga, Sheohar and Vaishali. The prominent marginal districts in Odisha for pulses are Khordha, Gajapati, Nuapada, Keonjhar and Angul.

The innovative technologies identified for the marginal districts in pulses in the two states are:

1. Stress-tolerant high-yielding varieties- A number of stress-tolerant high-yielding varieties for all major pulses have been developed by the public sector in India in recent years. The supply of these cultivars needs to be improved in both Bihar and Odisha. Over time, pulse production has moved from eastern to western India, just as it has moved from north to south. Eastern states like Bihar and Odisha have been losing out on pulses. This interregional movement, to some extent, was driven by technology. New varieties of pulses, viz. short-run and very-short-run varieties, after they were introduced in the late 1990s, allowed for intercropping in such a way that areas less successful in pulses subsequently became quite proficient in them.

2. Inter-cropping of pulses with other crops can be a highly remunerative practice (Singh et al. 2009). Pulses also help in nitrogen fixation. They should thus be promoted as part of the rationalization of fertilizer usage in Bihar and Odisha.

3. Some other technologies such as line sowing/seed drilling/zero tilling are useful practices for improving the yield of pulses. Use of Rhizobium culture, phosphatic fertilizers and micro-nutrients like Boron, Molybdenum, Sulphur should be promoted in pulses. 


\section{Market Infrastructure}

An overarching message that emerged from the elicitations in both Bihar and Odisha is that significant gains can accrue from the creation of marketing and storage infrastructure that will aid in the adoption of technology. Market development will strengthen the bargaining position of small and marginal farmers who end up selling the small surplus to middlemen or local traders at prices much lower than the government support price or the actual market price. In both states, since the central government does not procure grains, the farm gate prices are far below the minimum support price (MSP). Figure 18.4, which maps the markets across all districts in India (normalized by the number of cultivators), shows that these two states lag behind other states. With the realization of higher farm gate prices, higher incomes will strengthen the capacity of farmers to invest in new technologies.

\section{The Factors Behind Technology Adoption}

After selection of marginal districts and shortlisting of technologies, we take a snapshot of the technological options and gather details about their special features and the current state in terms of their uptake. Table 18.3 presents the details regarding technologies based on expert elicitations, focus group discussions, and a review of the literature supplemented with field visits. The main message from Table 18.3 is that technology adoption is a complex process involving several complementary inputs, and that the greater the role of these complementary inputs, the less likely it is for the technology to be adopted on a larger scale.

Several technologies in Bihar and Odisha listed in Table 18.3 have not moved much beyond the introduction stage. These include technologies like laser land leveling (LLL), mechanized direct seeded rice plantation (MDSR) (also mechanized zero tillage of wheat), and furrow irrigated bed planting, all of which have moved at a sluggish pace. Even simple technologies such as mid-season drainage through wetting and drying have only expanded at a slow rate. On the other hand, technologies such as drought- and flood-resistant varieties of crops had greater uptake. Constraints in adoption of technology differ, but generally, almost all technologies have been inhibited because of lack of adequate extension services and often because of missing complementary inputs. Table 18.3 presents the basic set of existing factors. such as agro-climatic conditions, that customize technologies to specific areas.

To illustrate the role of complementary inputs, consider the case of LLL. In spite of being a promising technology, it has spread in a limited way because of its capital costs that, under liquidity constraints, screen out small farmers. Another example in which pre-conditions for the spread of technology have not been in evidence is SRI. In spite of being a promising technology, the complementary inputs and riskiness 


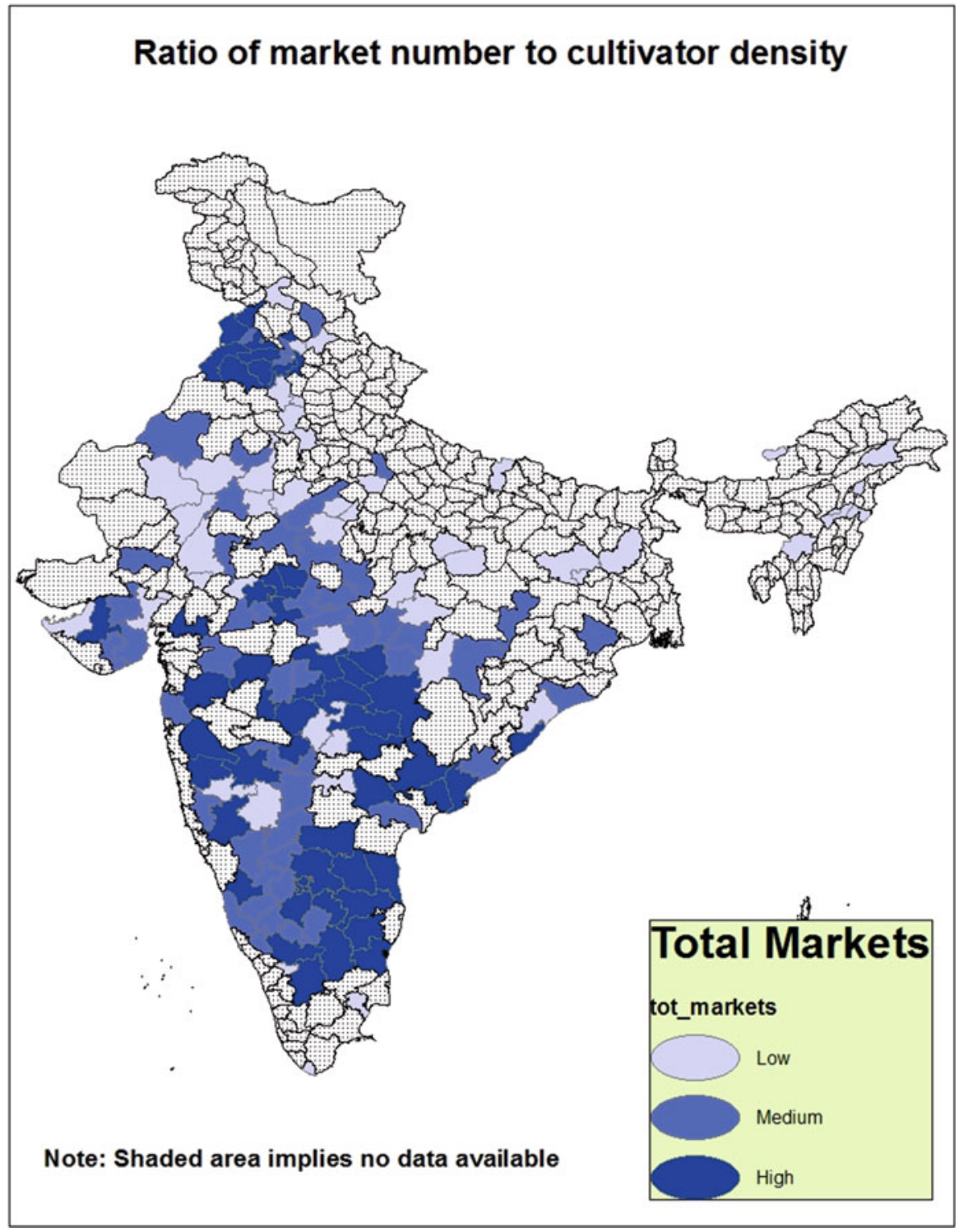

Fig. 18.4 Market density (normalized by number of cultivators)

inhibit large-scale adoption of this technology. With the basic information about technologies combined in Table 18.3, we developed the instruments for a primary survey of farmers regarding their awareness of and their adoption patterns for different technologies identified from the earlier workshops and expert elicitations. 


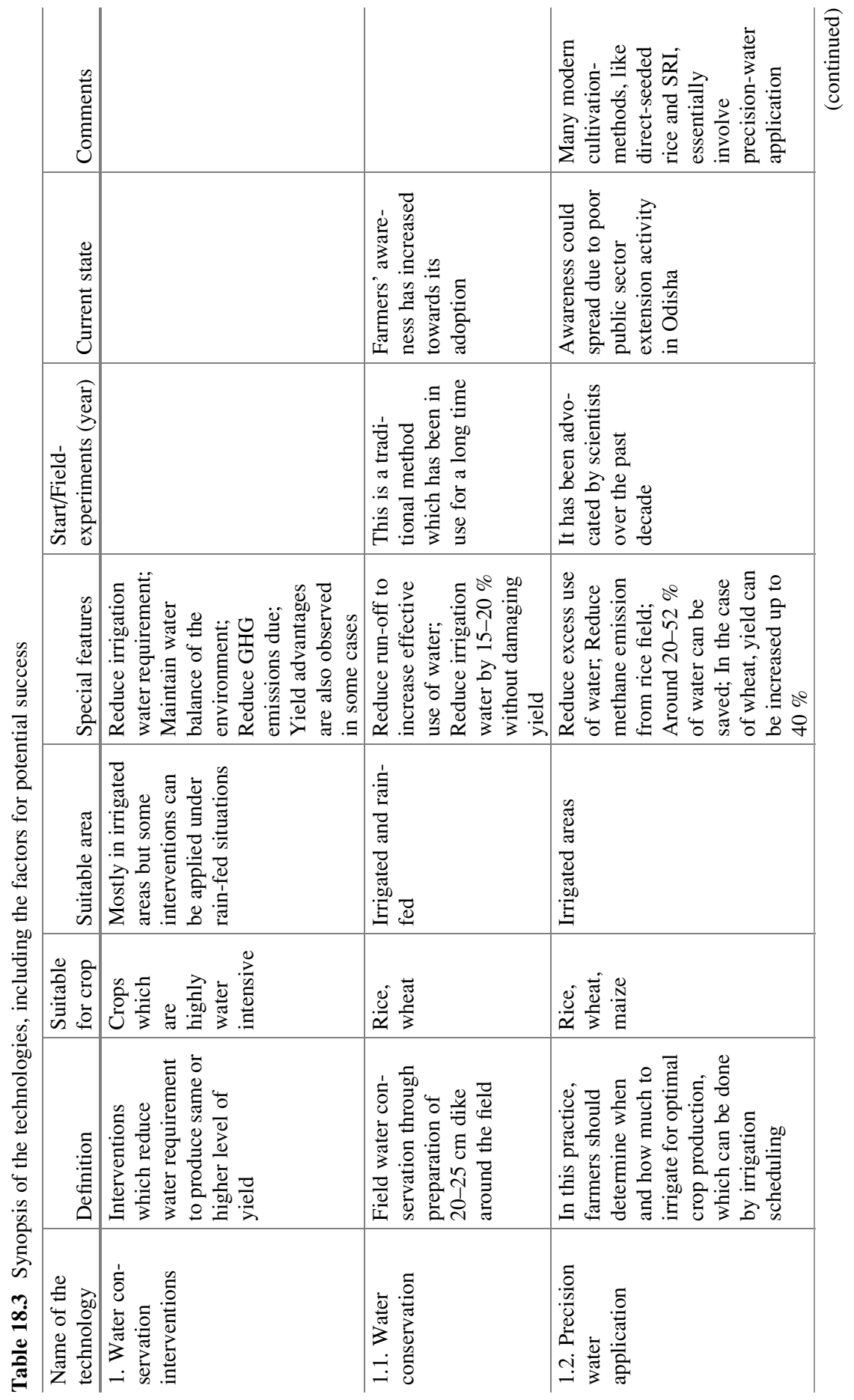




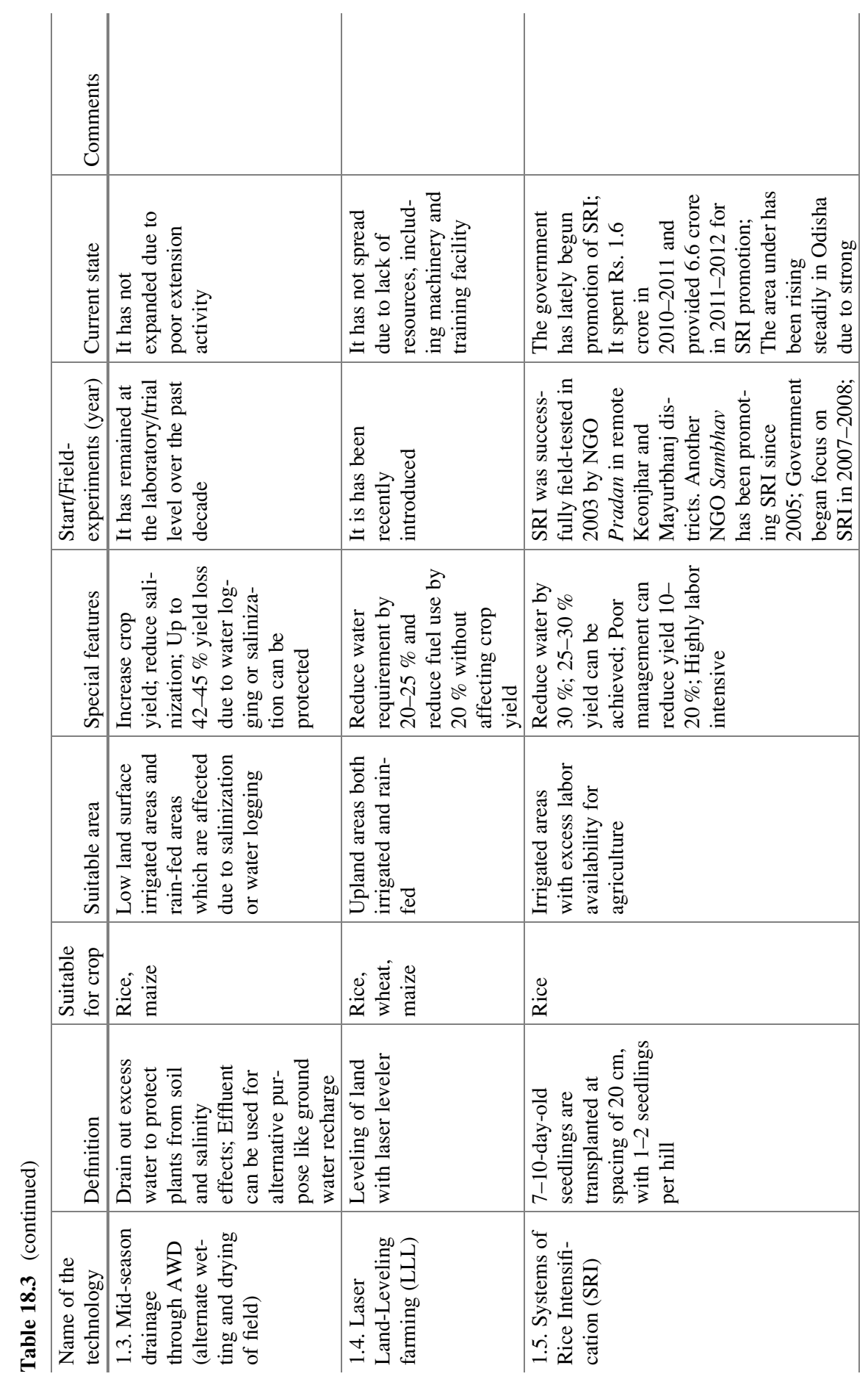




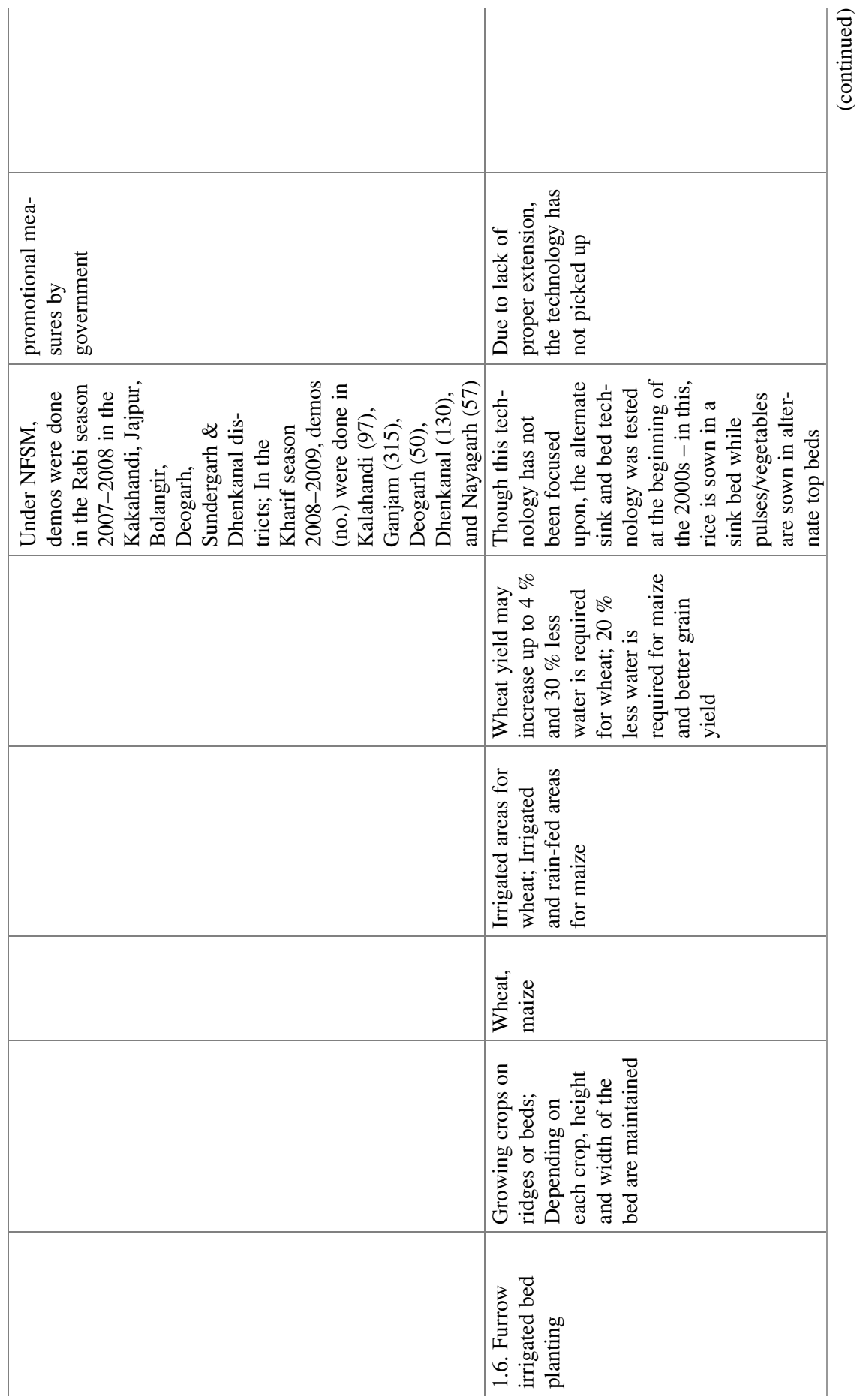




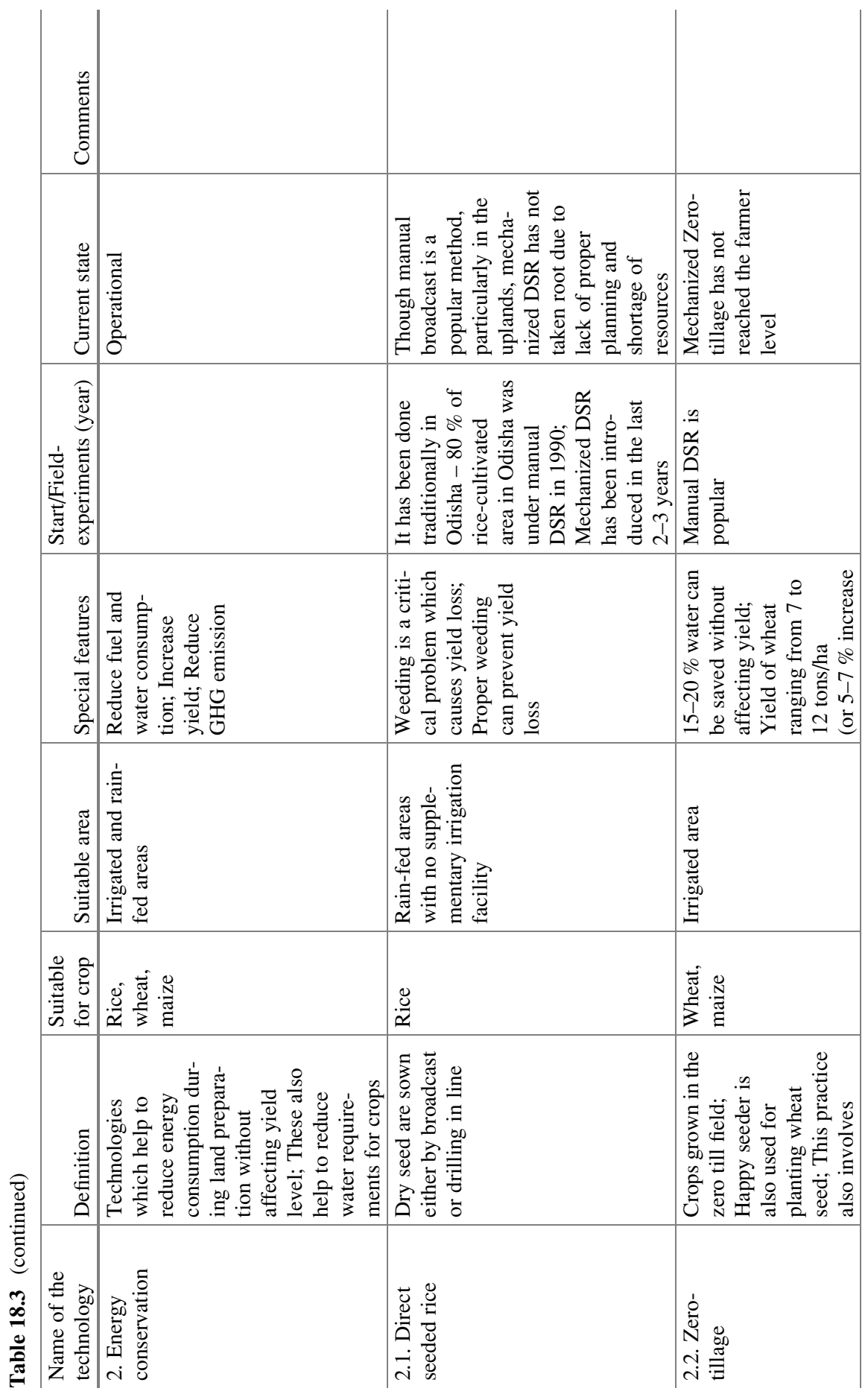




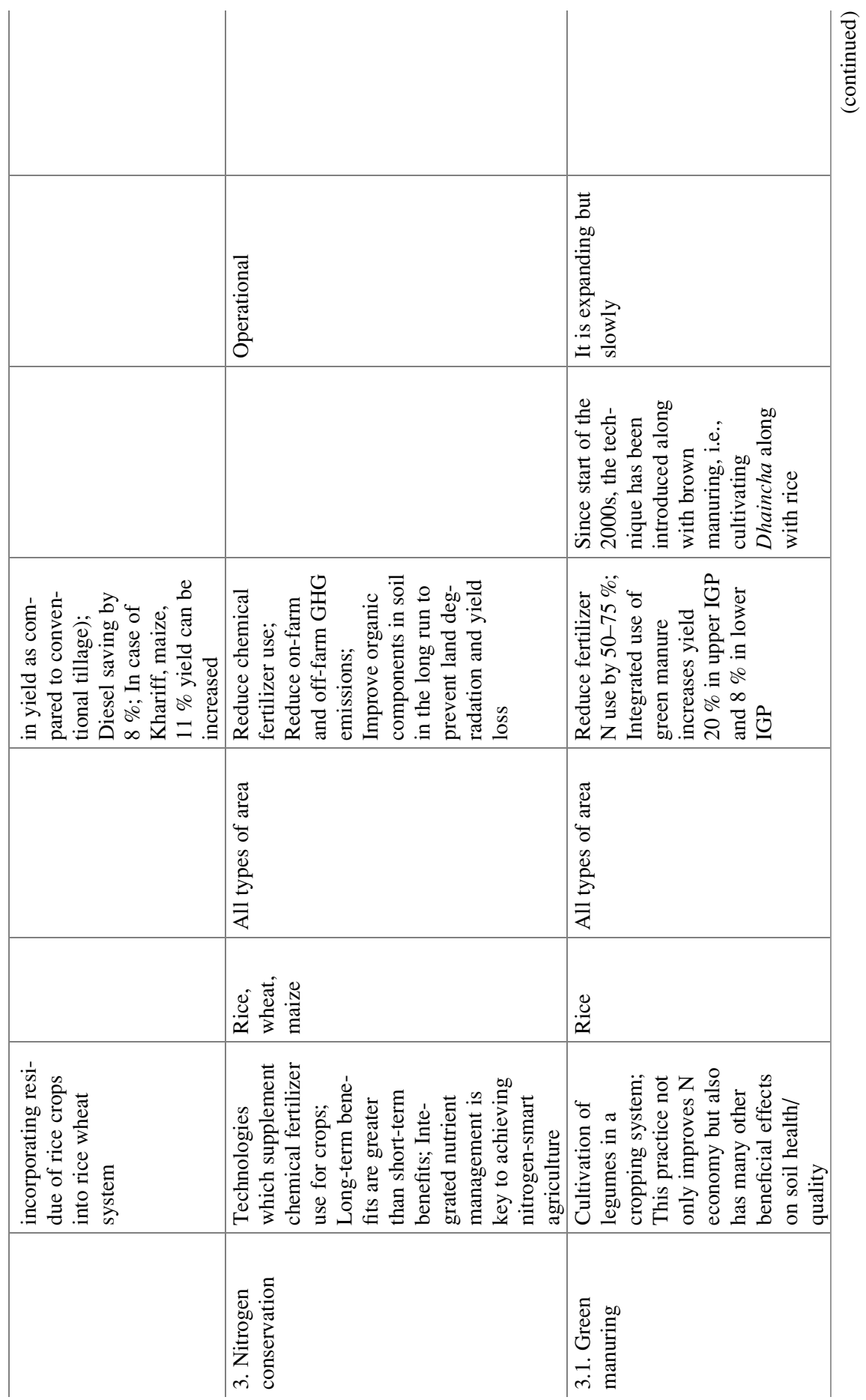




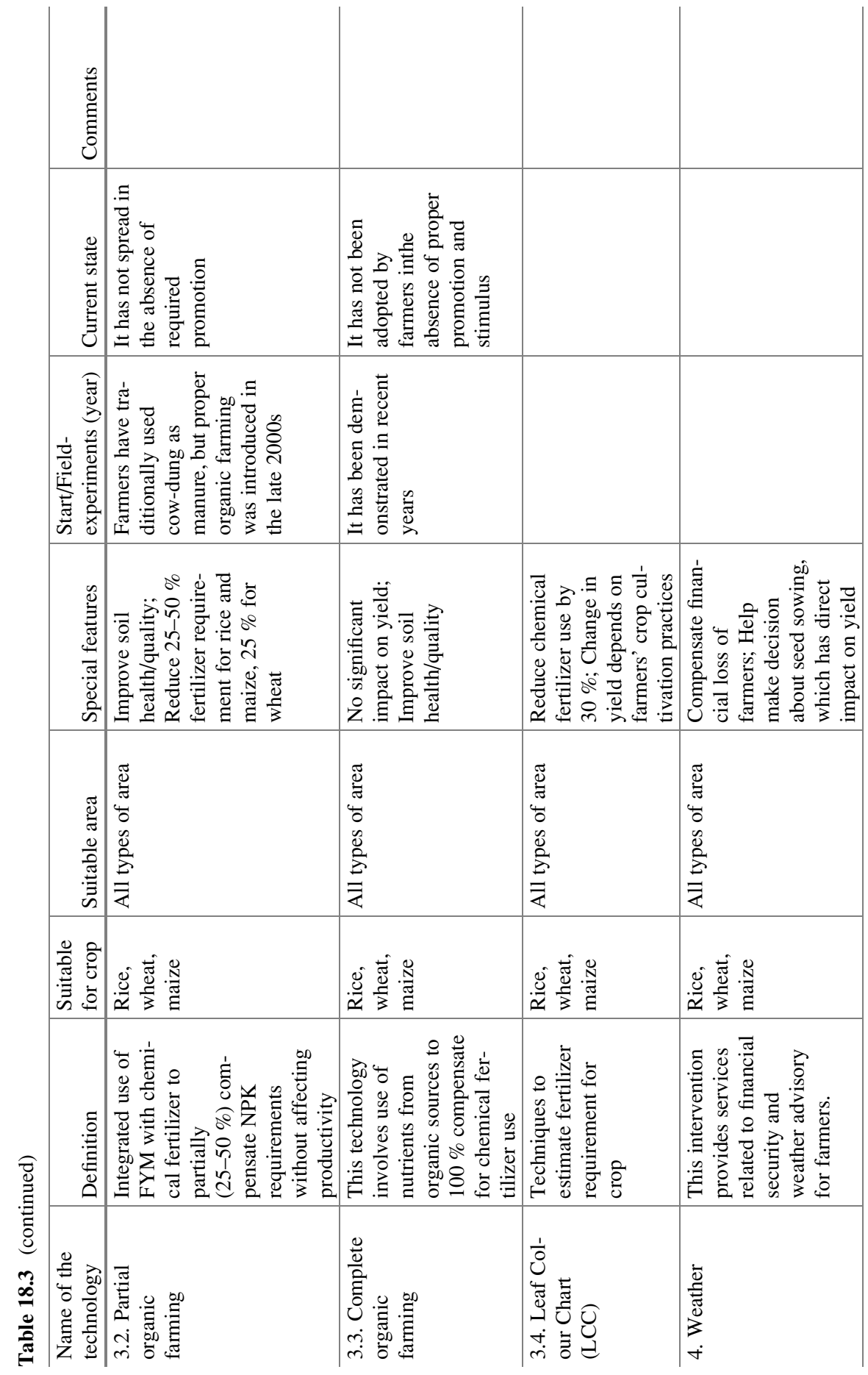




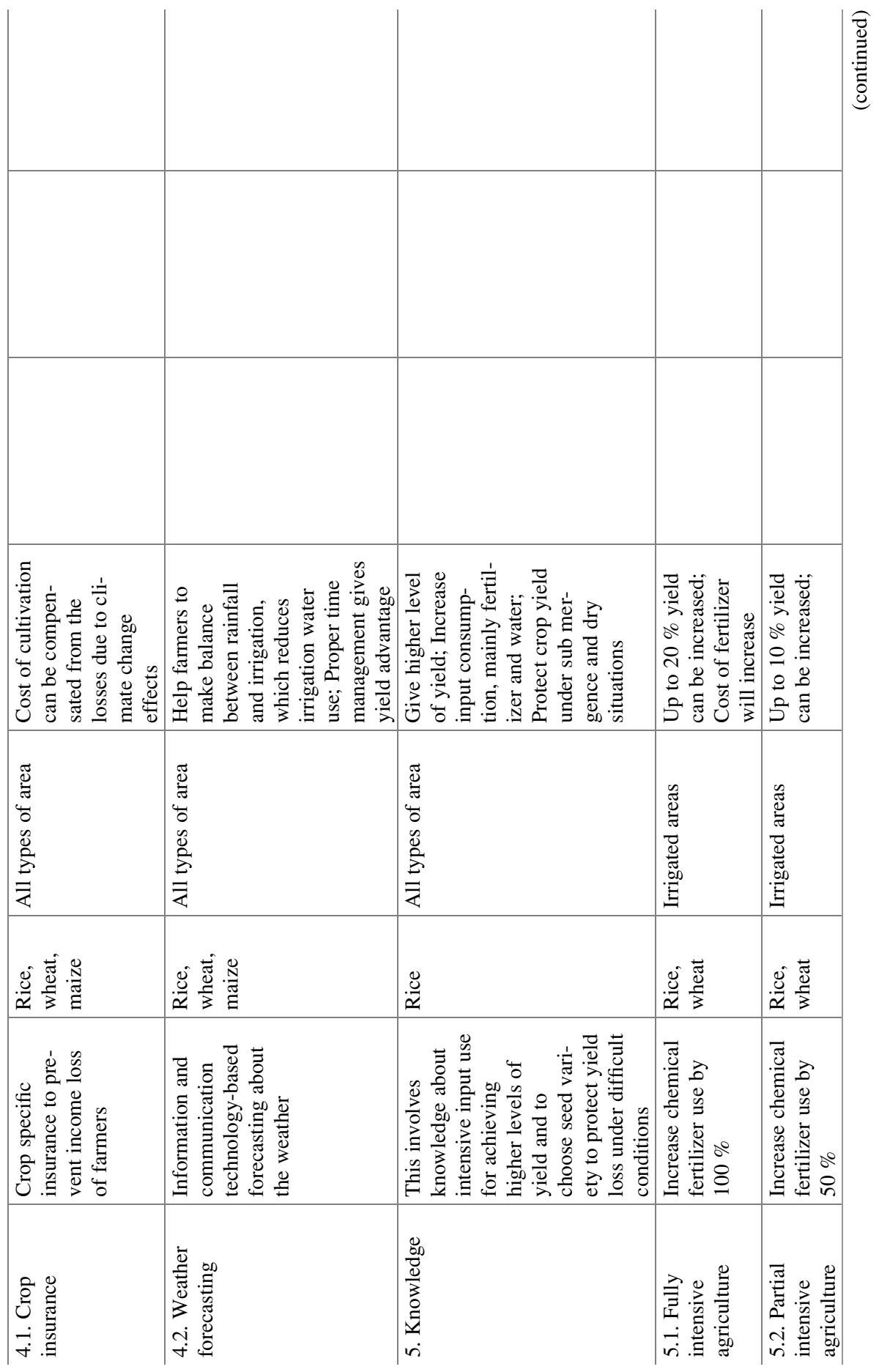




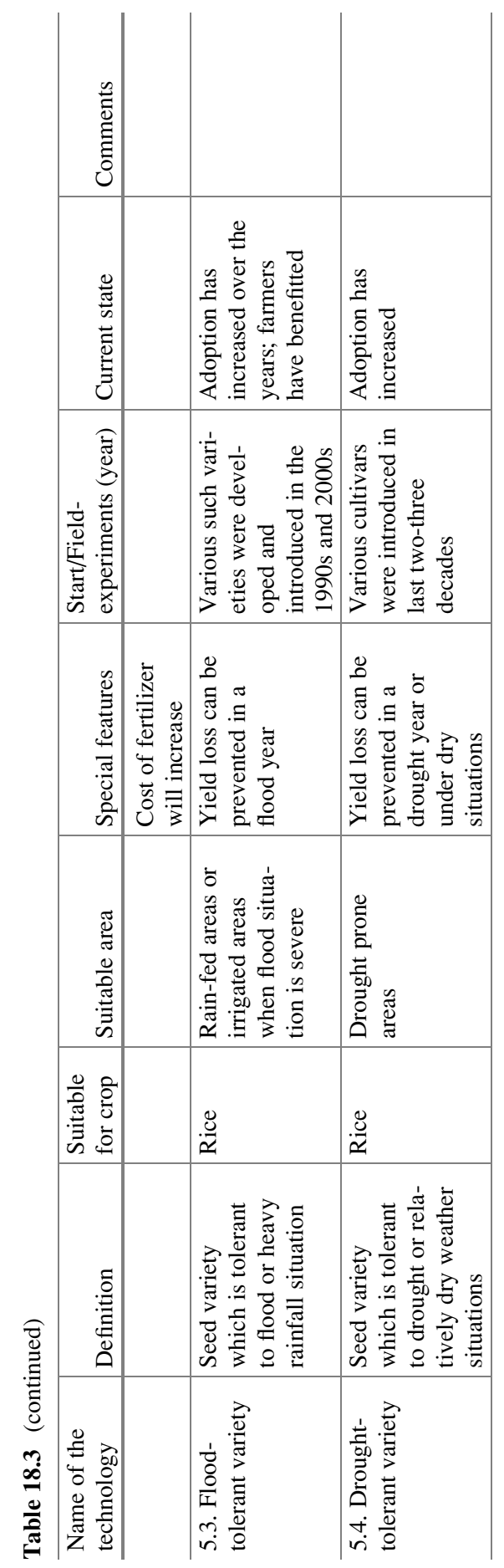




\section{Findings from the Farmer Survey}

After shortlisting the technologies and summarizing the factors behind technology adoption, we conducted primary surveys in three marginal districts each in both Bihar and Odisha. The structured questionnaires were designed to assess the state of awareness about different technologies and the level of adoption directly from farmers.

\section{Cropping Choices of Farmers}

Figure 18.5 presents the distribution of farmers by crop choices. As expected, the majority of farmers are engaged in cereal production, i.e., rice and wheat in Bihar and only rice in Odisha. Importantly, more than $40 \%$ of the farmers in Bihar are also engaged in maize production. Maize has been a revolutionary crop in Bihar in recent times and has surpassed the growth rate of production of other primary crops. In comparison, the uptake of maize in Odisha is smaller in the three districts with less than $4 \%$ of the farmers in our survey cultivating it. Another crop that has generally been neglected in both Bihar and Odisha is pulses, but technology interventions may turn out to be quite important for this crop.

\section{Summary Statistics from Farmer Survey}

Apart from current crop choices, the survey also asked farmers which crops or activities they are not engaged in but would like to get into. This could suggest the crops/activities for which the potential of technologies should be assessed, since farmers have expressed their willingness to get into these. Maize stands out as the crop, both in Bihar and Odisha, that a large proportion of farmers want to get involved in (Table 18.4). Note that the question is directed to the farmers not currently cultivating maize. Apart from maize, the sector that farmers want to get into if not currently engaged with is pulses. For Bihar and Odisha combined, more than $18 \%$ of farmers would like to get into pulses if they are currently not engaged with them. In looking for promising technologies for marginal districts in the two states, the ones related to maize and pulses should thus be given due attention.

Next, we analyze the status of technologies in terms of awareness and uptake from the point of the farmers from selected marginal districts in the two states. 


\section{Percent of farmers engaged in crops or activities}

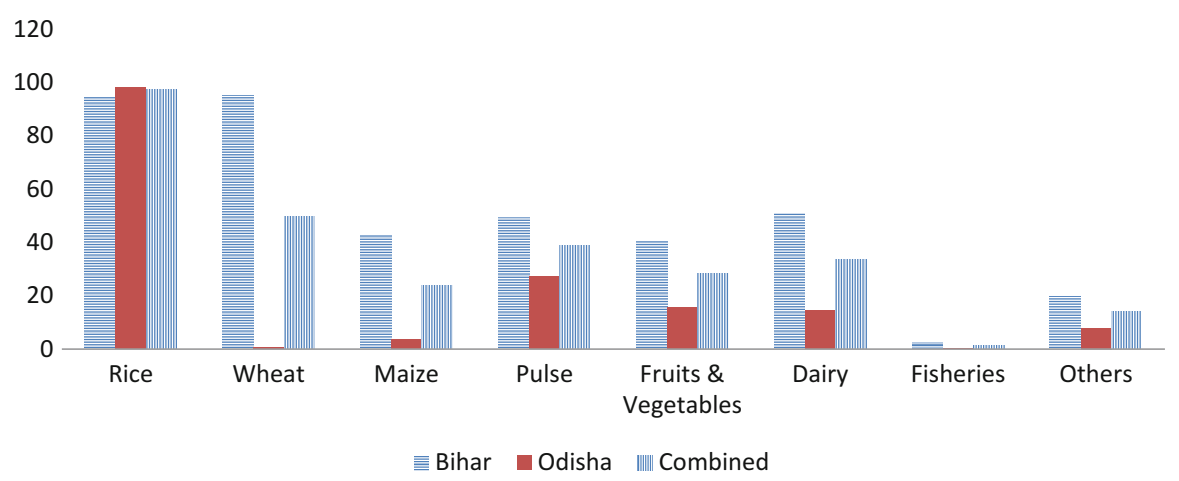

Fig. 18.5 Distribution of farmers by crop activity in Bihar and Odisha

Table 18.4 Farmer's revealed choices for activities other than the current activity in marginal districts

\begin{tabular}{l|c|c|c}
\hline & Bihar & Odisha & Combined \\
\hline Maize & 21.03 & 23.79 & 22.58 \\
\hline Pulses & 7.68 & 29.59 & 18.50 \\
\hline Fruits and vegetables & 13.52 & 42.75 & 27.99 \\
\hline Dairy & 13.52 & 10.64 & 12.23 \\
\hline Fisheries & 19.01 & 2.71 & 11.2 \\
\hline & 3.11 & 4.45 & 3.8 \\
\hline
\end{tabular}

Source: Field survey data

\section{Awareness of Technologies and Their Adoption in Bihar and Odisha}

\section{Demographic, Asset and Amenities Characteristics}

Characteristics such as education and experience in farming determine the likelihood of farmers being aware of certain technologies and adopting them. In addition, scale of production (reflected in size of landholdings) and social identity also seem to play a role. Access to credit, markets, information and other complimentary factors determining adoption of technology are often functions of land size and the social identity of the farmer.

About $30 \%$ of the farmers in the Bihar sample are completely or partially illiterate and only $6 \%$ have some college experience. Similarly, about $30 \%$ of farmers in the Odisha sample are illiterate. These farmers, however, have significant experience in farming. There is less experience with spring and winter maize, but those cultivating them, on average, have over one and a half decade's experience with the crop (Fig. 18.6). 


\section{Average Experience (in Years)}

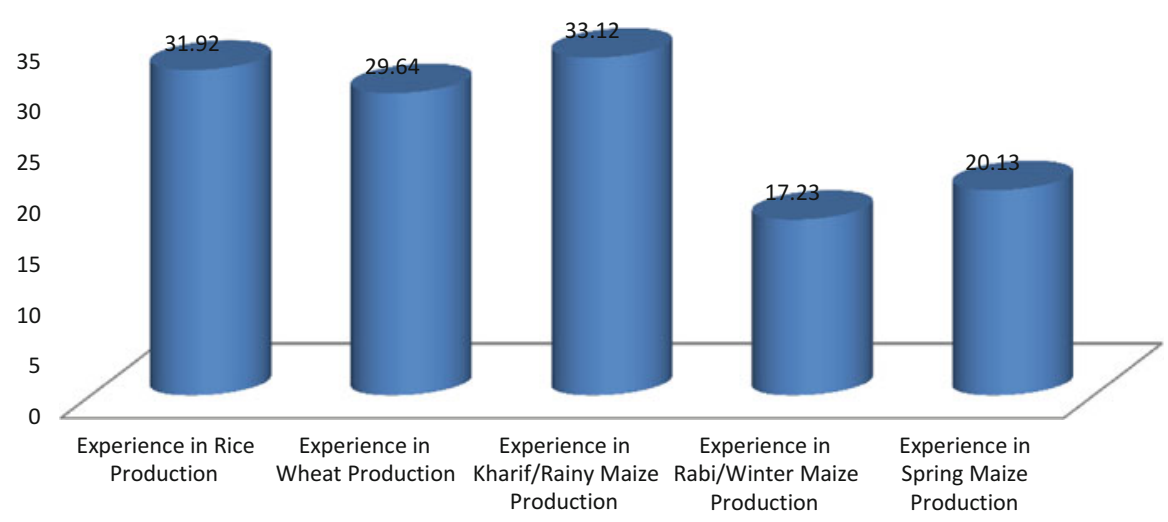

Fig. 18.6 Experience in farming in Bihar

Though a large share of farmers in the surveyed districts in Bihar own land (greater than $82 \%$ ), there is a significant share of sharecroppers in the sample (nearly $12 \%$ ). The incidence of sharecropping is lower in Odisha at less than $6 \%$. The rental contracts have high payment (either half or one third of the production) and risk-sharing is minimal. The ability to experiment with new technology would, thus, be quite limited for the renters. The evidence on land reforms and/or tenancy in regard to productivity has, however, been mixed (see Ghatak and Roy 2007).

In addition, the land markets are quite thin, with only $7 \%$ of the farmers in the three districts owning purchased land. The case is starker in Odisha, with less than $2 \%$ of the farmers having purchased or sold land. A technology that is scale dependent (for example, LLL) would face roadblocks in the current land ownership, market and tenure situation.

Another important characteristic that needs to be kept in mind about the marginal districts surveyed is that over $20 \%$ of the land is low-lying and $50 \%$ is medium-lying. In the case of Odisha, this figure is extremely high at nearly $40 \%$. Furthermore, in Odisha's surveyed districts, over $35 \%$ of the land has sandy soil, a characteristic that has implications for choice of technology.

On the positive side, the availability of irrigation, even in these marginal districts in Bihar, is high. Nearly $95 \%$ of the farmers surveyed have access to some form of pump irrigation, either on their own or by hiring. However, the intensity of irrigation (i.e., the number of times a plot is irrigated) is sub-optimal. In sharp contrast, more than $95 \%$ of the land in the marginal districts surveyed in Odisha are rain-fed (Fig. 18.7). There is, however, a greater coverage of canal irrigation, at $14 \%$, in Odisha than in Bihar. 


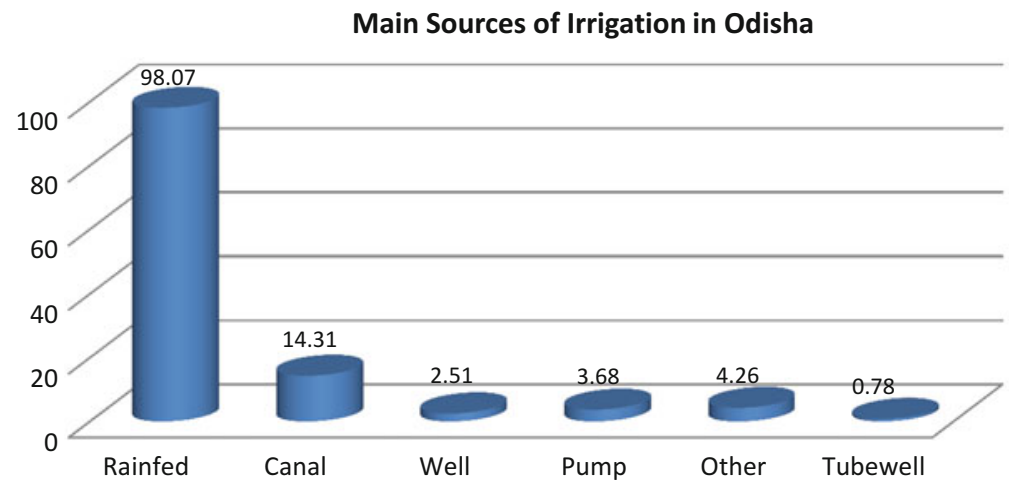

Fig. 18.7 Sources of irrigation in Odisha's surveyed marginal districts

\section{Land Size, Social Identity, Awareness and Adoption of Technology}

Based on our farmer survey, there are several salient findings regarding the association of socio-economic characteristics with technology choices, as follows.

(i) For the lowest caste group SC/ST, the proportion of farmers in both a high and a low state of landholdings (4th and 1st quartile of land distribution), there is a general lack of awareness about technology. (See Bhadauria 2013 for an account of differences in technology adoption across castes in agriculture). There are several barriers to technology adoption based on caste, some of which have been studied rigorously, for example, credit in Kumar (2013).

(ii) The level of awareness as well as implementation of technology for the other backward caste is high, at times greater than the higher caste farmers, but that could be related to the level of engagement with farming vis-à-vis non-farm activities.

(iii) Some technologies, like mechanized DSR and SRI, have low conversion from awareness to implementation. In general, translation from awareness to implementation rises with the holding size. Farmers in any social group are more likely to adopt a technology the greater their landholding is.

Fig. 18.8 presents the awareness of technologies across crops. ${ }^{5}$ There is a definite pecking order in awareness of technology, with farmers belonging to the lowest

\footnotetext{
${ }^{5}$ The test for awareness of technology was based on the surveyed farmer being able to explain the technology in a way that revealed their knowledge of its details. For example, several farmers confused the simple traditional way of broadcasting with the mechanical direct seeding of rice. Enumerators had to ensure that the knowledge of the technology was not being confounded with similar but technically different methods.
} 


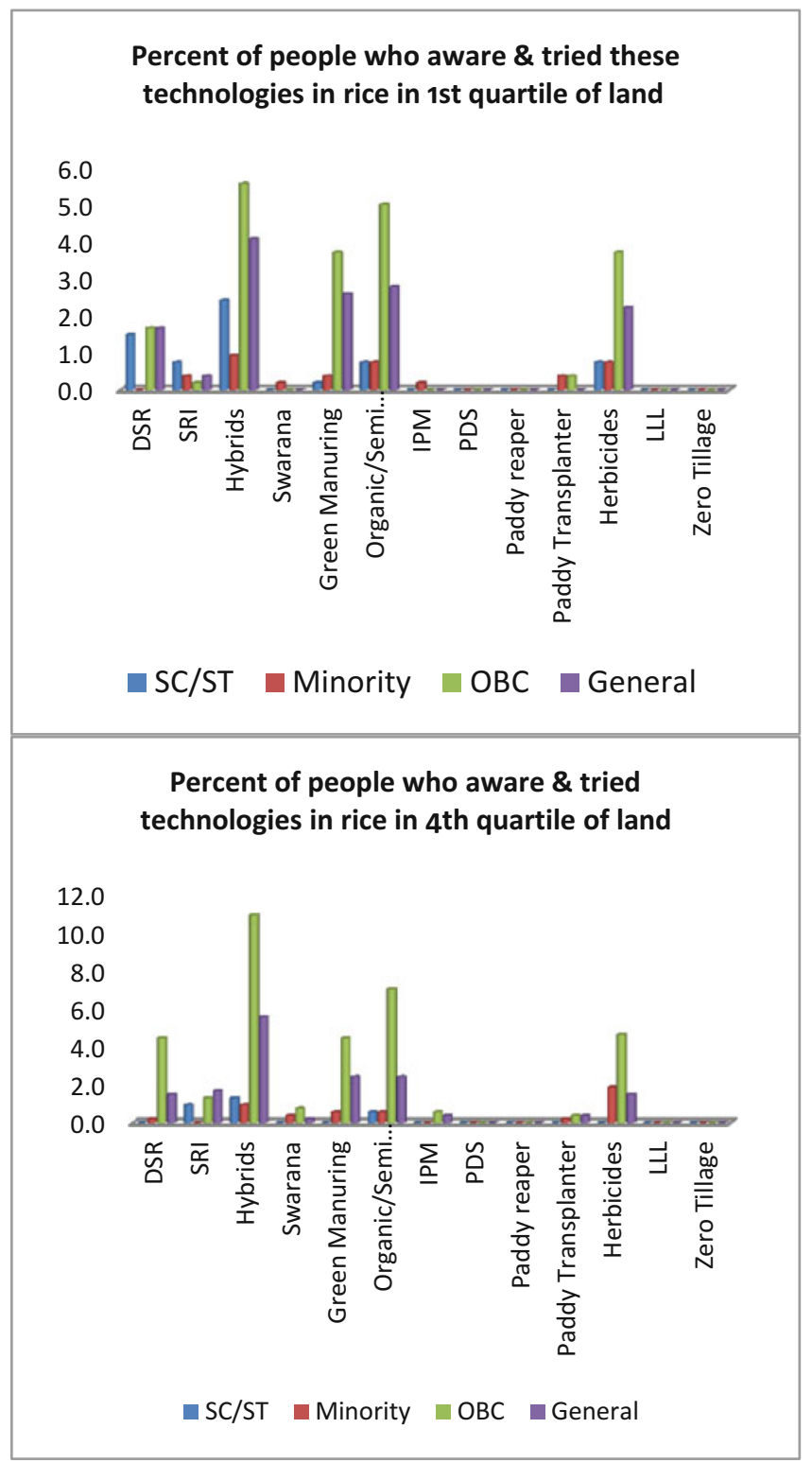

Fig. 18.8 Percentage of farmers adopting technology conditional on awareness 


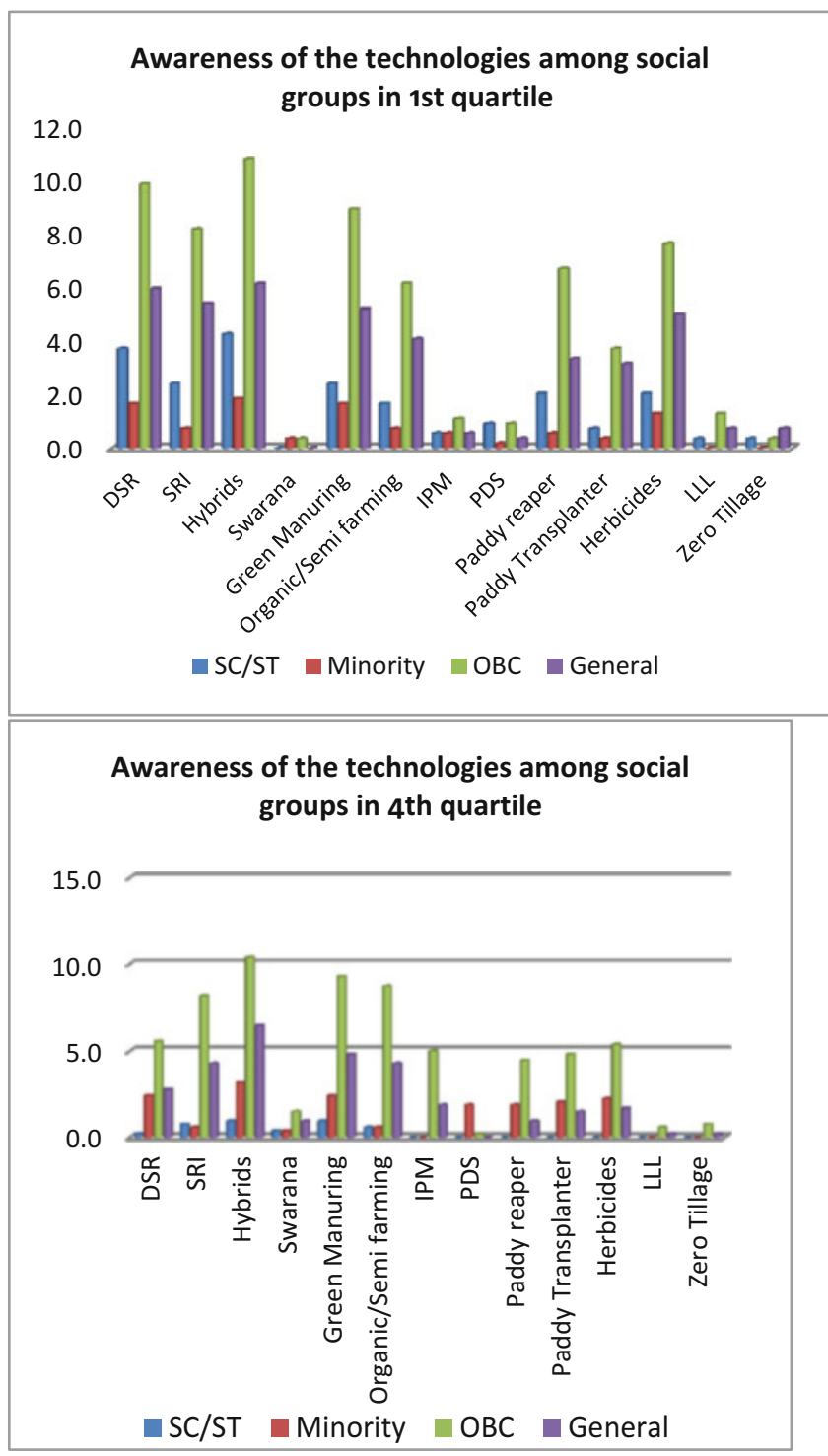

Fig. 18.9 Awareness of rice technology: variation by social identity and landholdings 
caste and the minority groups being generally less aware. Moreover, some of the disadvantages based on social identity seem to be mitigated as land size increases. Larger low caste farmers are generally more aware of technologies (Fig. 18.9).

\section{Awareness and Adoption Among Farmers in Marginal Districts: Technologies in Rice}

Apart from farm and farmer characteristics, underlying the awareness and adoption of technologies are the roles of different social and institutional networks. As a source of information, expectedly, the most common networks comprise friends and neighbors. The public extension services are hardly the main sources of information, being more so in Odisha. This reinforces the possibility discussed in various circles that one of the most important factors preventing adoption of promising technologies is the lack of extension support. According to Birner and Anderson (2007), the public extension system in India has been unable to keep pace with the changes in the global technological and economic environments. With increasing demand for information, the extension system has evolved to include various information sources, including public and private, formal and informal, and traditional and modern.

In Bihar, while over $5 \%$ of farmers got the information about their chosen technology from public sector extension services, in Odisha, it was less than $2 \%$. Print and electronic media account for a meager $4 \%$ of the information farmers obtained about rice technologies (those who actually adopted them).

There are several technologies in rice for which awareness is strikingly low. Consider, for example, integrated pest management (IPM). Though shortlisted as a frontal technology, in both states, less than $7 \%$ of farmers are aware of IPM. Also striking is the extremely low level of awareness of the Swarna submersible variety of rice. It is possible that only those farmers who have low-lying land prone to flooding would seek information on such varieties. Indeed, awareness of this variety is marginally higher (by about 2 percentage points) among farmers with low-lying land.

Also, upon awareness, adoption is not automatic. Figure 18.10 shows that, for some much publicized technologies in rice, for example, mechanized DSR and SRI, conditional on awareness, adoption is almost negligible (more so for the latter). In particular, SRI has extremely low adoption among farmers in the marginal districts, even though it has been marketed as a technology with very high potential in the scientific community. Table 18.5 above shows the pitfalls in this technology, wherein it would require several complementary inputs if it were to be adopted. Farmer surveys also show that farmers are wary of the downside risk with SRI. If, for example, there are untimely rains when young saplings are planted, the losses would be quite significant. A contrast to such situations in adoption of technology is hybrid rice in Bihar. More than $60 \%$ of the surveyed farmers have adopted hybrid 


\section{Percent of farmers who tried technologies in Rice}

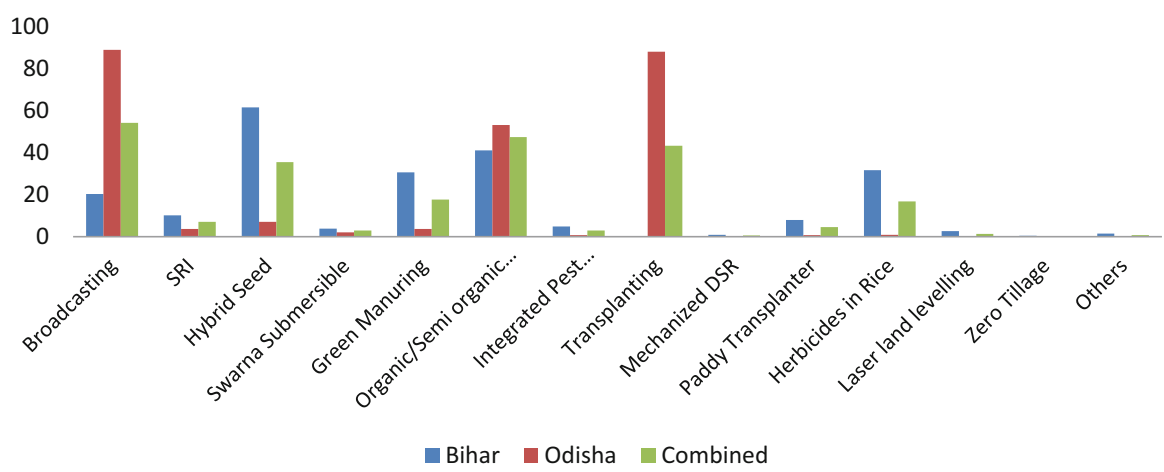

Fig. 18.10 Percentage of adopters of technologies in rice

Table 18.5 Constraints in technology adoption in rice

\begin{tabular}{l|c|c}
\hline Constraints & Bihar & Odisha \\
\hline Technology expensive and/or credit constraints & 72.58 & 94.20 \\
\hline Lack of economic availability of inputs & 51.37 & 54.55 \\
\hline High downside risk & 43.51 & 46.81 \\
\hline Higher levels of production but markets for output not commensurate & 16.27 & 12.57 \\
\hline Information constraints & 35.10 & 33.85 \\
\hline Technology relatively new and I do not want to be the experimenter & 10.79 & 40.23 \\
\hline Observation of several failures of technology & 5.48 & 6.19 \\
\hline Technology delivers positive gains but far below the promise & 1.46 & 4.06 \\
\hline Others & 2.01 & 0.19 \\
\hline
\end{tabular}

rice. This figure is especially striking since hybrid rice has been introduced only recently. However, the adoption of hybrid rice in Odisha is comparatively low (Fig. 18.10).

Furthermore, almost $65 \%$ of the farmers in marginal districts who are currently not cultivating hybrid rice would like to adopt it. It is, in fact, the most aspirational technology for farmers in marginal districts of both states. Organic/semi-organic farming is another technology which the non-practitioners aspire to (30\% and $28 \%$ farmers in Bihar and Odisha, respectively). Note that aspiration for technologies does not imply that the respective farmers have the right set of conditions to actually adopt them. Importantly, some technologies, like zero tillage and LLL, are not sought after, despite again being cases in which high potential has been accorded to them by scientists.

With awareness and aspiration in place, what are the factors that inhibit technology adoption? We compiled a list of possible inhibitors in this context. The set of constraints are given below in Table 18.5, any number of which could be working in combination. Results on the farmers' responses regarding the bind of different constraints in adoption of technologies in rice are presented below 

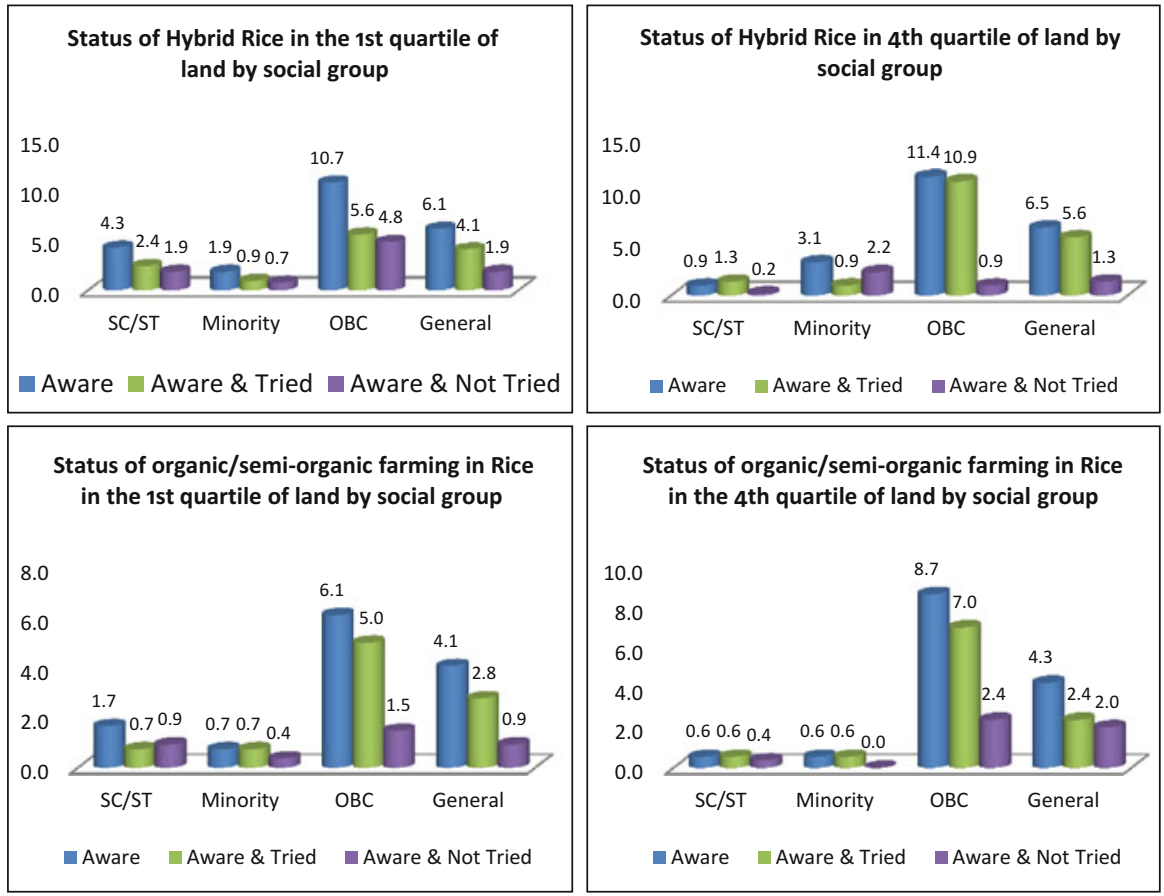

Fig. 18.11 Hybrid rice and organic/semi-organic farming in rice

(Table 18.5). In both states, the hindrances to adoption of technologies in rice are broadly similar (with only a few exceptions). Credit is a bigger constraint in Odisha than it is in Bihar. Also, the farmers in marginal districts of Odisha are comparatively averse to experimentation. Almost identical proportions of farmers in both Bihar and Odisha face information problems with regard to technologies in rice (nearly $35 \%$ ).

Similar to hybrid rice, organic and semi-organic farming is also marked by awareness commonly translating into adoption. In rice, the two technologies that could be promoted further in the marginal rice districts are hybrid varieties and organic/semi-organic farming, as there is near universal uptake across socioeconomic categories (Fig. 18.11). While the awareness and uptake of organic/ semi-organic rice farming is similar in Odisha, hybrid rice has extremely low uptake by farmers in the marginal districts of Odisha, at $7 \%$ compared to over $61 \%$ in Bihar. 


\section{Percent of farmers aware of these technologies in Wheat}

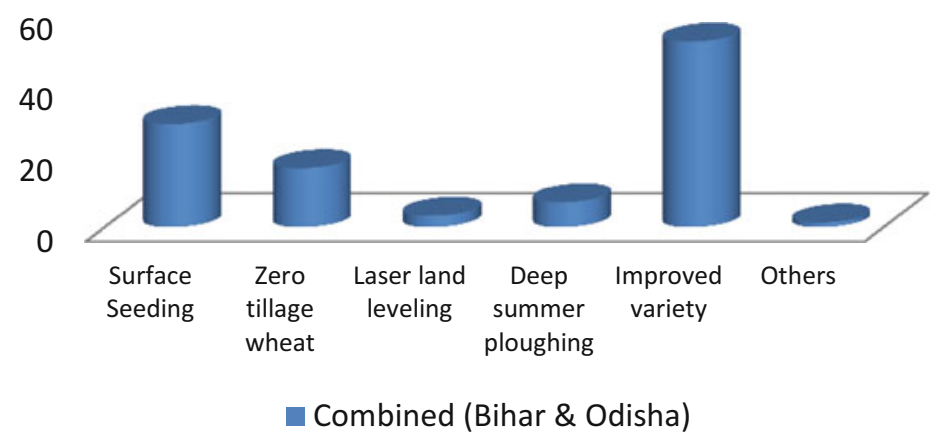

Fig. 18.12 Percentage share of farmers aware of technologies in wheat

\section{Percent of farmers who tried these technologies in Wheat}

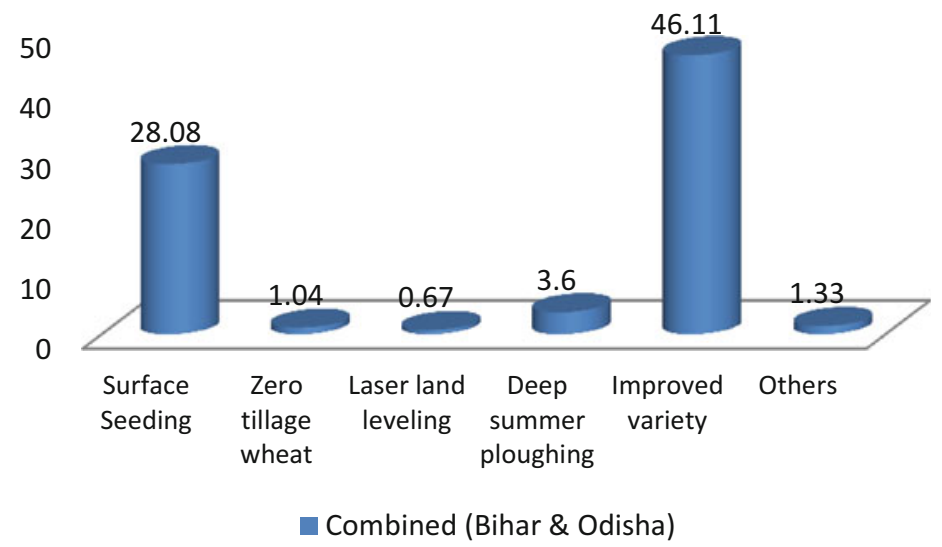

Fig. 18.13 Share of farmers trying technologies in wheat

\section{Awareness of Technologies in Wheat: Zero Tillage Wheat, LLL and Other Technologies}

Repeating the same exercise used for rice, Figs. 18.12 and 18.13 present the awareness of wheat technologies and their adoption. Among the technologies, the highest awareness and adoption levels belong to improved varieties in wheat. Technologies like LLL have not taken off in wheat (as they have failed to do in rice) in the marginal districts of Bihar. In fact, a very small proportion of farmers are even aware of LLL. Furthermore, in contrast with the findings based on expert 


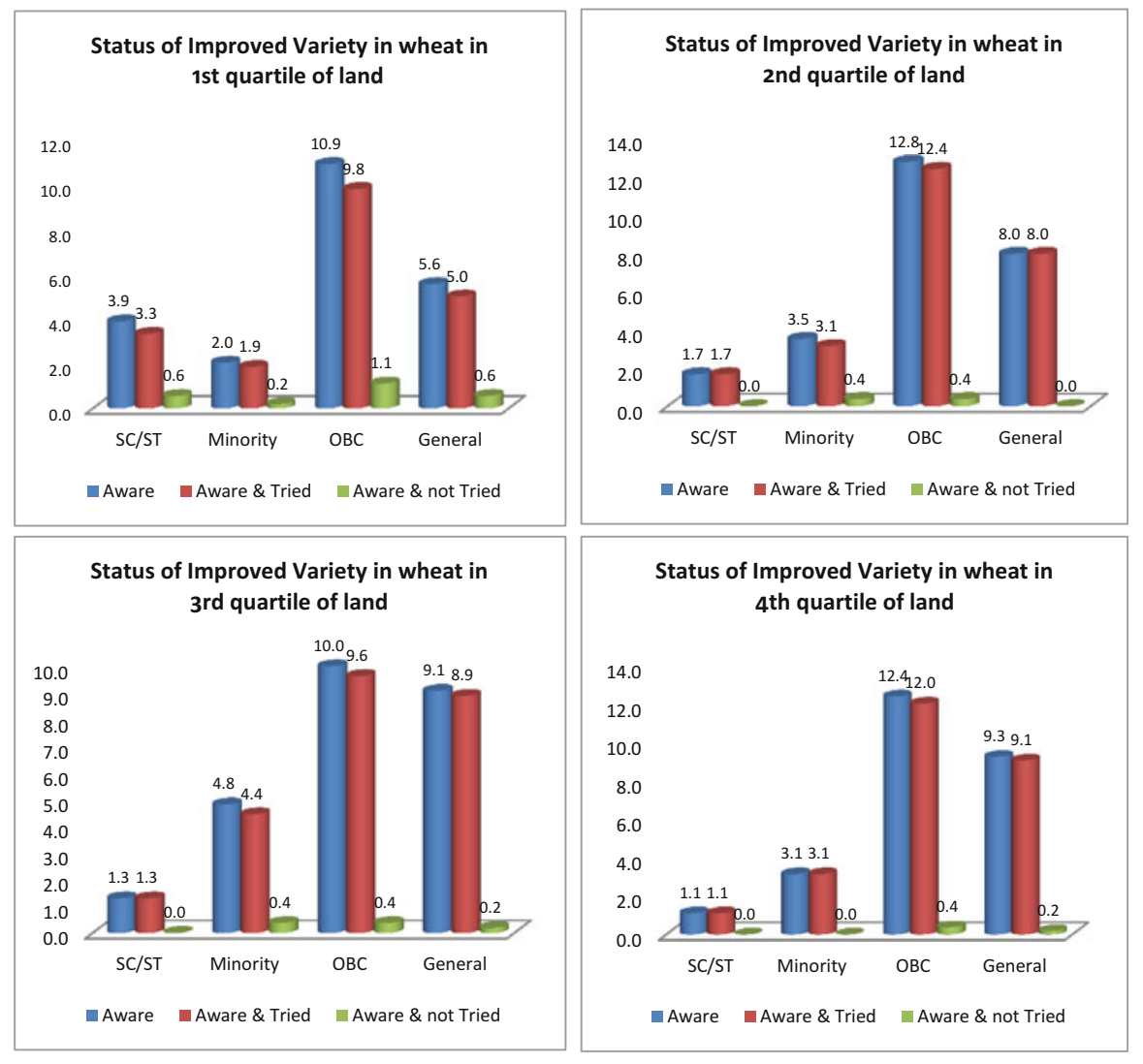

Fig. 18.14 Awareness and adoption of improved varieties in wheat

elicitation, only about $20 \%$ of farmers are aware of mechanized zero tillage technology (MZTT). Both in the case of MZTT as well as that of LLL, data shows an extremely low share of farmers trying these methods.

In the marginal districts, what mechanized DSR and SRI are to rice, zero tillage and LLL are to wheat. Projected as highly promising, the awareness and adoption levels are extremely low for these technologies. In the lowest caste groups, there is absolutely no awareness of these technologies. Even in the higher caste categories and in the highest land size group (the 4th quartile of land distribution), the scenario is similar (data not presented here).

The most important technology for wheat that has widespread awareness and good conversion from awareness to adoption in the marginal districts is improved varieties. The farmers are more commonly updated with improved varieties and reveal a high propensity for adopting them. The awareness and subsequent adoption of improved varieties in wheat is indiscriminately high across social groups and land sizes (Fig. 18.14). 


\section{Percent of people who thinks specific technologies as most promising and will like to get into it}

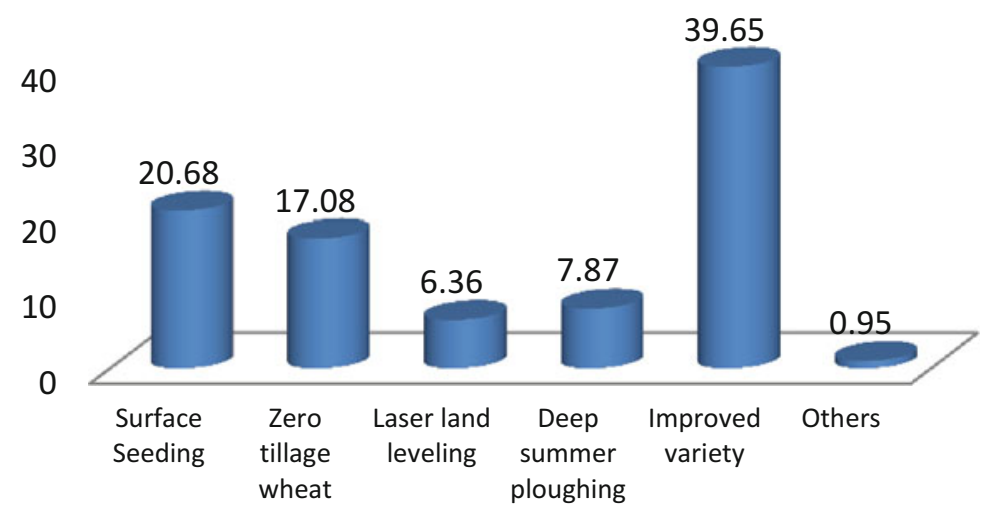

Fig. 18.15 Proportion of informed farmers aspiring for different untried technologies in wheat

Moreover, in deciding about technologies for marginal areas, one criterion can be conditional on information about a technology, namely what fraction of farmers would likely adopt it. Clearly, technologies that farmers reveal their aspirations for are more likely to be adopted. Figure 18.15 presents the percentage of farmers who find specific technologies to be most promising and would likely adopt them. The demand pull is clearly weak for LLL and deep summer ploughing.

Promoting improved varieties of wheat would likely have the greatest uptake among farmers. Other technologies such as surface seeding and ZTWT are also likely to find some acceptance. These revealed preferences are, however, based on the existing information sets of the farmers. If the information sets of the farmers themselves were to be altered, that would change the situation in regard to the valuation of the farmers.

\section{Farmer's Choice of Technologies in Maize}

An important role played by technology has been to make maize a multi-seasonal fixture, as opposed to a rainy season-specific crop. Thus, the analysis of maize has to be done by season. Across states, there are significant differences in both awareness as well as application of maize technologies between Bihar and Odisha. Based on the survey, in the marginal districts, over $42 \%$ of farmers are engaged in maize cultivation in Bihar. The corresponding figures for Odisha are less than $3.5 \%$. Yet, maize remains a promising crop in Odisha, with nearly $24 \%$ of farmers not engaged currently aspiring to get into it. 
Awareness of hybrid varieties in maize is quite widespread, particularly in Bihar, where more than half of the farmers surveyed know about them. In both Bihar and Odisha, an area where a large scope remains for improving the knowledge set of farmers, their adoption is related to the high value of corn products like Quality Protein Maize for feed, in particular, baby corn and sweet corn, respectively. The percentage of farmers who think of these as profitable options is in the single digits.

Importantly, in the marginal districts of both Bihar and Odisha, we do not have a single farmer in our sample who has tried producing baby corn or sweet corn. These are high value corn items and promoting them can augment farm incomes significantly. This is true for the cases of both winter and spring maize. In terms of the constraints inhibiting adoption of hybrid maize, the survey shows the main reason is lack of availability of seeds.

\section{Farmer's Perspective and Choice of Technologies in Pulses}

More than half of the farmers in Bihar in our sample are engaged in pulses. The corresponding number for Odisha is much lower at $27 \%$. In both states, pulses need to fit into the cereal production cycle. Importantly, a technology that has been generally suggested to improve the outcomes in production is intercropping of pulses with different crops. In both states, the survey results show that the incidence of intercropping is limited. Less than $1 \%$ of pulse farmers engage in intercropping, mainly with rice, maize or vegetables. This is one area in pulse production that needs to be scaled up.

Our survey did not ask specific questions about awareness regarding technologies in pulses. In terms of adoption of varieties, the dominance of local seeds is paramount, particularly in Mung, a very important pulse in Bihar and Odisha. Among pulse-growing farmers, more than $95 \%$ of farmers use local seeds and improved varieties are rarely chosen.

\section{Regression Analysis for Awareness and Adoption of Technologies in Rice, Wheat and Maize in Bihar and Odisha}

Below, we explore the determinants of technology adoption in a more rigorous fashion through regression analysis, looking for general factors that are associated with awareness of technology, as well as its adoption. As discussed above, there are significant context specificities across technologies. Yet, there are also broad generalities in the context of technologies that can help us to understand the typology of the awareness and adoption of technologies. Regressions are aimed at 
identifying the target groups and characteristics that are linked with the knowledge of farmers about technologies and their propensities in adopting them.

Tables 18.6, 18.7, and 18.8 present the marginal effects of the variables in a probit regression for awareness and adoption of technologies in rice, wheat and maize in the three marginal districts of Bihar and Odisha. We pick up three frontline technologies in each crop to assess the level of association of each technology with characteristics of the farmers. Some of the associations with farmer, plot and location characteristics are crop- and technology-specific, but some are more generic. Specifically, the technologies analyzed below are, in rice, hybrid rice, SRI and DSR; in wheat, surface seeding, improved varieties and zero tillage; and in maize, hybrid maize, optimal spacing and nutrient management.

Specifically, we are interested in the characteristics of the former, such as land size and social identity, apart from demographic characteristics such as age, experience in farming and levels of education (human capital). As part of the pathway towards the uptake of technology, we also assess whether awareness, as well as adoption, is associated with different information sources, viz, public extension services, private information sources (such as input dealers) and social networks such as friends and neighbors. There is a growing body of literature that finds evidence of social learning in technology adoption (see, for example, Foster and Rosenzweig 2010; Pomp and Burger 1995).

The probit regressions in Tables 18.6, 18.7, and 18.8 control for several farmer and farm characteristics. Importantly, observed and unobserved regional characteristics are accounted for in all regressions with the inclusion of block fixed effects. Furthermore, given the possibility of correlated unobserved factors at the regional level, all standard errors are clustered at the block level. Hence, the agro climatic conditions and external factors such as distance from the markets and other time invariant location characteristics are controlled for in these regressions. Our main variables of interest are landholding characteristics, social identity variables and the main sources of information for the technology. There is very little variation in the size of landholding per plot. Yet, to take into account the differences that result from landholding, we include a number of plots owned by a farmer for which there is much greater variation in the cross-sectional data.

Several stylized facts and general features emerge from the basic regression analysis for the technologies in the three crops. These are as follows:

1. Landholding characteristic in the form of number of plots is positively and significantly associated with awareness, as well as adoption, of most technologies across the three crops. In most technologies, farmers with greater number of plots tend to be aware of technology and are also more likely to adopt. A greater number of plots likely allows for experimentation with new technology by spreading out risk. Only in the case of maize did a greater number of plots not have a distinctive effect on adoption of technologies. Land size per se does not have a significant effect on choice of technology, but that is probably because of the nature of the data, which in these marginal districts comprises very little variation in the holding sizes across households. 
Table 18.6 Awareness and adoption of technologies in rice: marginal effects from probit regressions

\begin{tabular}{|c|c|c|c|c|c|c|}
\hline & DSR & SRI & Hybrid & $\begin{array}{l}\text { Tried } \\
\text { DSR }\end{array}$ & $\begin{array}{l}\text { Tried } \\
\text { SRI }\end{array}$ & $\begin{array}{l}\text { Tried } \\
\text { Hybrid } \\
\text { rice }\end{array}$ \\
\hline Household size & $\begin{array}{l}-0.007 \\
{[0.021]}\end{array}$ & $\begin{array}{l}0.022 \\
{[0.018]}\end{array}$ & $\begin{array}{l}0.008 \\
{[0.024]}\end{array}$ & $\begin{array}{l}0.003 \\
{[0.02]}\end{array}$ & $\begin{array}{l}0.004 \\
{[0.03]}\end{array}$ & $\begin{array}{l}-0.02 \\
{[0.01]}\end{array}$ \\
\hline $\begin{array}{l}\text { Household head } \\
\text { age }\end{array}$ & $\begin{array}{l}-0.011^{*} \\
{[0.006]}\end{array}$ & $\begin{array}{l}-0.014 * * * \\
{[0.005]}\end{array}$ & $\begin{array}{l}-0.009 \\
{[0.008]}\end{array}$ & $\begin{array}{l}0.012 \\
{[0.01]}\end{array}$ & $\begin{array}{l}-0.01 \\
{[0.008]}\end{array}$ & $\begin{array}{l}0.013 * * \\
{[0.007]} \\
\end{array}$ \\
\hline $\begin{array}{l}\text { Household head } \\
\text { experience in } \\
\text { farming }\end{array}$ & $\begin{array}{l}0.021 * * * \\
{[0.003]}\end{array}$ & $\begin{array}{l}0.010^{*} \\
{[0.006]}\end{array}$ & $\begin{array}{l}0.011 \\
{[0.007]}\end{array}$ & $\begin{array}{l}-0.0 \\
{[0.005]}\end{array}$ & $\begin{array}{l}0.011 \\
{[0.01]}\end{array}$ & $\begin{array}{l}-0.02 * * * \\
{[0.007]}\end{array}$ \\
\hline Number of plots & $\begin{array}{l}0.037 * * * \\
{[0.011]}\end{array}$ & $\begin{array}{l}0.047 * * * \\
{[0.008]}\end{array}$ & $\begin{array}{l}0.012 \\
{[0.012]}\end{array}$ & $\begin{array}{l}0.024 * * \\
{[0.012]}\end{array}$ & $\begin{array}{l}0.003 \\
{[0.017]}\end{array}$ & $\begin{array}{l}0.026 * * * \\
{[0.010]}\end{array}$ \\
\hline Total plot area & $\begin{array}{l}-0.032 \\
{[0.031]} \\
\end{array}$ & \begin{tabular}{|l|}
-0.032 \\
{$[0.022]$} \\
\end{tabular} & \begin{tabular}{|l|}
0.001 \\
{$[0.017]$}
\end{tabular} & $\begin{array}{l}-0.01 \\
{[0.02]}\end{array}$ & $\begin{array}{l}0.042 \\
{[0.029]}\end{array}$ & \begin{tabular}{|l|}
0.022 \\
{$[0.025]$} \\
\end{tabular} \\
\hline $\begin{array}{l}\text { Receiving non- } \\
\text { agricultural } \\
\text { income }\end{array}$ & $\begin{array}{l}-0.44 * * * \\
{[0.128]}\end{array}$ & $\begin{array}{l}-0.118 \\
{[0.184]}\end{array}$ & $\begin{array}{l}-0.283 * * \\
{[0.115]}\end{array}$ & $\begin{array}{l}-0.117 \\
{[0.149]}\end{array}$ & $\begin{array}{l}0.553 * * * \\
{[0.196]}\end{array}$ & $\begin{array}{l}0.433 * * * \\
{[0.154]}\end{array}$ \\
\hline $\begin{array}{l}\text { Household mem- } \\
\text { ber receiving } \\
\text { some income } \\
\text { from NREGA }\end{array}$ & $\begin{array}{l}-0.191 \\
{[0.210]}\end{array}$ & $\begin{array}{l}-0.213 * * \\
{[0.103]}\end{array}$ & $\begin{array}{l}0.096 \\
{[0.130]}\end{array}$ & $\begin{array}{l}0.214 \\
{[0.144]}\end{array}$ & $\begin{array}{l}0.211 \\
{[0.283]}\end{array}$ & $\begin{array}{l}0.117 \\
{[0.147]}\end{array}$ \\
\hline $\begin{array}{l}\text { Dummy for clay } \\
\text { soil }\end{array}$ & $\begin{array}{l}-0.188 \\
{[0.365]}\end{array}$ & $\begin{array}{r}-0.095 \\
{[0.261]}\end{array}$ & $\begin{array}{l}-0.138 \\
{[0.273]}\end{array}$ & $\begin{array}{l}0.212 \\
{[0.315]}\end{array}$ & $\begin{array}{l}-0.328 \\
{[0.742]}\end{array}$ & $\begin{array}{l}-0.177 \\
{[0.248]}\end{array}$ \\
\hline $\begin{array}{l}\text { Dummy for } \\
\text { loamy soil }\end{array}$ & $\begin{array}{l}-0.062 \\
{[0.167]}\end{array}$ & $\begin{array}{l}0.410^{*} \\
{[0.243]}\end{array}$ & \begin{tabular}{|l|}
-0.061 \\
{$[0.239]$}
\end{tabular} & $\begin{array}{l}0.259 \\
{[0.245]}\end{array}$ & $\begin{array}{l}0.250 \\
{[0.398]}\end{array}$ & $\begin{array}{l}0.029 \\
{[0.229]}\end{array}$ \\
\hline $\begin{array}{l}\text { Dummy for } \\
\text { sandy soil }\end{array}$ & $\begin{array}{l}0.081 \\
{[0.260]}\end{array}$ & $\begin{array}{l}0.550 * * \\
{[0.234]}\end{array}$ & \begin{tabular}{|l|}
0.151 \\
{$[0.312]$} \\
\end{tabular} & $\begin{array}{l}-0.185 \\
{[0.336]}\end{array}$ & $\begin{array}{l}0.293 \\
{[0.531]}\end{array}$ & \begin{tabular}{|l|}
0.349 \\
{$[0.283]$} \\
\end{tabular} \\
\hline $\begin{array}{l}\text { Dummy sched- } \\
\text { uled caste ( }=1 \text { if } \\
\text { yes, } 0 \text { if no) }\end{array}$ & $\begin{array}{l}-0.009 \\
{[0.252]}\end{array}$ & $\begin{array}{l}-0.63^{* * *} \\
{[0.196]}\end{array}$ & $\begin{array}{l}-0.359^{*} \\
{[0.207]}\end{array}$ & $\begin{array}{l}0.116 \\
{[0.278]}\end{array}$ & $\begin{array}{l}-0.243 \\
{[0.471]}\end{array}$ & $\begin{array}{l}-0.676^{* *} \\
{[0.288]}\end{array}$ \\
\hline $\begin{array}{l}\text { Dummy sched- } \\
\text { uled tribe }(=1 \text { if } \\
\text { yes, } 0 \text { if no })\end{array}$ & $\begin{array}{l}-0.056 \\
{[0.471]}\end{array}$ & $\begin{array}{l}-0.506^{*} \\
{[0.275]}\end{array}$ & $\begin{array}{l}-0.472 \\
{[0.417]}\end{array}$ & $\begin{array}{l}-0.143 \\
{[0.299]}\end{array}$ & $\begin{array}{l}-0.241 \\
{[0.577]}\end{array}$ & $\begin{array}{l}-0.083 \\
{[0.287]}\end{array}$ \\
\hline $\begin{array}{l}\text { Dummy other } \\
\text { backward caste } \\
\text { (=1 if yes, } 0 \text { if } \\
\text { no) }\end{array}$ & $\begin{array}{l}-0.226 \\
{[0.167]}\end{array}$ & $\begin{array}{l}-0.251^{*} \\
{[0.132]}\end{array}$ & $\begin{array}{l}-0.095 \\
{[0.242]}\end{array}$ & $\begin{array}{l}-0.085 \\
{[0.169]}\end{array}$ & $\begin{array}{l}0.017 \\
{[0.299]}\end{array}$ & $\begin{array}{l}-0.081 \\
{[0.174]}\end{array}$ \\
\hline $\begin{array}{l}\text { Dummy minority } \\
(=1 \text { if yes, } 0 \text { if } \\
\text { no) }\end{array}$ & $\begin{array}{l}0.041 \\
{[0.359]}\end{array}$ & $\begin{array}{l}-0.269 \\
{[0.294]}\end{array}$ & $\begin{array}{l}-0.268 \\
{[0.427]}\end{array}$ & $\begin{array}{l}-0.234 \\
{[0.46]}\end{array}$ & $\begin{array}{l}-0.536 \\
{[0.543]}\end{array}$ & $\begin{array}{l}-0.295 \\
{[0.288]}\end{array}$ \\
\hline $\begin{array}{l}\text { Dummy no } \\
\text { schooling ( }=1 \text { if } \\
\text { yes, }=0 \text { if no) }\end{array}$ & $\begin{array}{l}-0.02 \\
{[0.38]}\end{array}$ & $0.05[0.327]$ & $\begin{array}{l}0.28 \\
{[0.26]}\end{array}$ & $\begin{array}{l}-0.503 \\
{[0.359]}\end{array}$ & $\begin{array}{l}5.115 * * * \\
{[0.414]}\end{array}$ & \begin{tabular}{|c|}
-0.241 \\
{$[0.301]$}
\end{tabular} \\
\hline $\begin{array}{l}\text { Dummy middle } \\
\text { school (=1 if } \\
\text { yes, }=0 \text { if no) }\end{array}$ & $\begin{array}{l}-0.089 \\
{[0.383]}\end{array}$ & $\begin{array}{l}0.329 \\
{[0.333]}\end{array}$ & \begin{tabular}{|l}
0.237 \\
{$[0.240]$}
\end{tabular} & $\begin{array}{l}-0.695^{*} \\
{[0.345]}\end{array}$ & $\begin{array}{l}5.4^{* * * *} \\
{[0.302]}\end{array}$ & $\begin{array}{l}0.004 \\
{[0.34]}\end{array}$ \\
\hline
\end{tabular}


Table 18.6 (continued)

\begin{tabular}{|c|c|c|c|c|c|c|}
\hline & DSR & SRI & Hybrid & $\begin{array}{l}\text { Tried } \\
\text { DSR }\end{array}$ & $\begin{array}{l}\text { Tried } \\
\text { SRI }\end{array}$ & $\begin{array}{l}\text { Tried } \\
\text { Hybrid } \\
\text { rice }\end{array}$ \\
\hline $\begin{array}{l}\text { Dummy high } \\
\text { school (=1 if } \\
\text { yes, }=0 \text { if no) }\end{array}$ & $\begin{array}{l}-0.190 \\
{[0.423]}\end{array}$ & $0.32[0.318]$ & $\begin{array}{l}0.416 \\
{[0.321]}\end{array}$ & $\begin{array}{l}-0.527 \\
{[0.355]}\end{array}$ & $\begin{array}{l}5.6^{* * *} \\
{[0.365]}\end{array}$ & $\begin{array}{l}0.213 \\
{[0.370]}\end{array}$ \\
\hline $\begin{array}{l}\text { Dummy interme- } \\
\text { diate degree }(=1 \\
\text { if yes, }=0 \text { if no) }\end{array}$ & $\begin{array}{l}0.040 \\
{[0.347]}\end{array}$ & $\begin{array}{l}0.577 * \\
{[0.343]}\end{array}$ & $\begin{array}{l}0.471 \\
{[0.344]}\end{array}$ & $\begin{array}{l}-0.73 * * \\
{[0.373]}\end{array}$ & $\begin{array}{l}5.73 * * * \\
{[0.347]}\end{array}$ & $\begin{array}{l}0.088 \\
{[0.426]}\end{array}$ \\
\hline $\begin{array}{l}\text { Dummy for } \\
\text { bachelor's } \\
\text { degree (=1 if } \\
\text { yes, }=0 \text { if no) }\end{array}$ & $\begin{array}{l}0.131 \\
{[0.468]}\end{array}$ & $\begin{array}{l}0.701 * * \\
{[0.315]}\end{array}$ & $\begin{array}{l}1.049^{* *} \\
{[0.434]}\end{array}$ & & & \\
\hline $\begin{array}{l}\text { Dummy for } \\
\text { information from } \\
\text { friend/neighbor } \\
(1=\text { yes, =0 if } \\
\text { no) }\end{array}$ & $\begin{array}{l}0.373^{* *} \\
{[0.148]}\end{array}$ & $\begin{array}{l}0.367 * * \\
{[0.149]}\end{array}$ & $\begin{array}{l}0.530^{* * * *} \\
{[0.155]}\end{array}$ & $\begin{array}{l}0.254 \\
{[0.184]}\end{array}$ & $\begin{array}{l}-0.282 \\
{[0.248]}\end{array}$ & $\begin{array}{l}0.215^{*} \\
{[0.129]}\end{array}$ \\
\hline $\begin{array}{l}\text { Dummy for } \\
\text { information from } \\
\text { public extension } \\
\text { (=1 if yes, =0 if } \\
\text { no) }\end{array}$ & $\begin{array}{l}-0.152 \\
{[0.373]}\end{array}$ & $\begin{array}{l}0.438 \\
{[0.388]}\end{array}$ & $\begin{array}{l}0.640 \\
{[0.530]}\end{array}$ & $\begin{array}{l}0.552 \\
{[0.482]}\end{array}$ & $\begin{array}{l}0.692 * \\
{[0.413]}\end{array}$ & $\begin{array}{l}0.499 \\
{[0.483]}\end{array}$ \\
\hline $\begin{array}{l}\text { Dummy for } \\
\text { information from } \\
\text { private extension } \\
\text { (=1 if yes, =0 if } \\
\text { no) }\end{array}$ & $\begin{array}{l}-1.282^{*} \\
{[0.757]}\end{array}$ & $\begin{array}{l}0.265 \\
{[0.624]}\end{array}$ & $\begin{array}{l}-0.489 \\
{[0.439]}\end{array}$ & $\begin{array}{l}-0.97 * * * \\
{[0.31]}\end{array}$ & $0.99[0.7]$ & $\begin{array}{l}1.142 * * * \\
{[0.371]}\end{array}$ \\
\hline $\begin{array}{l}\text { Yield range in } \\
\text { rice }\end{array}$ & & & & $\begin{array}{l}-0.013 \\
{[0.071]}\end{array}$ & $\begin{array}{l}-0.078 \\
{[0.061]}\end{array}$ & $\begin{array}{l}-0.062 \\
{[0.051]}\end{array}$ \\
\hline $\begin{array}{l}\text { Block fixed } \\
\text { effects }\end{array}$ & Yes & Yes & Yes & Yes & Yes & Yes \\
\hline Observations & 713 & 818 & 803 & 708 & 636 & 738 \\
\hline
\end{tabular}

Robust standard errors in parentheses $-* * * \mathrm{p}<0.01, * * \mathrm{p}<0.05, * \mathrm{p}<0.1$. All standard errors are clustered at the district level

2. Younger farmers are more likely to be aware of the technologies. Age has no effect on knowledge about certain technologies, or, if it does affect, it does not do so negatively. In general, experience in farming also raises the probability of being aware of technologies and the likelihood of adopting them.

3. One of the broadly generalizable results is the social bias in awareness, as well as adoption, of technology. There are several technologies for which evidence shows that the lowest caste strata is disadvantaged in terms of having knowledge about technologies, as well as adopting them. For example, this is true for awareness of SRI and hybrid rice. Hybrid rice, the spread of which has been extensive in Bihar, still has a situation in which the scheduled caste and scheduled tribe households have a significantly lower probability of being 
Table 18.7 Awareness and adoption of technologies in wheat: marginal effects from probit regressions

\begin{tabular}{|c|c|c|c|c|c|}
\hline & $\begin{array}{l}\text { Improved } \\
\text { variety }\end{array}$ & $\begin{array}{l}\text { Surface } \\
\text { seeding }\end{array}$ & $\begin{array}{l}\text { Zero } \\
\text { tillage } \\
\text { wheat }\end{array}$ & $\begin{array}{l}\text { Tried } \\
\text { improved } \\
\text { variety }\end{array}$ & $\begin{array}{l}\text { Tried } \\
\text { surface } \\
\text { seeding }\end{array}$ \\
\hline Household size & $\begin{array}{l}0.071 * * \\
{[0.030]}\end{array}$ & $\begin{array}{l}-0.029 \\
{[0.023]}\end{array}$ & $\begin{array}{l}-0.014 \\
{[0.026]}\end{array}$ & $\begin{array}{l}0.008 \\
{[0.056]}\end{array}$ & $\begin{array}{l}-0.042 \\
{[0.026]}\end{array}$ \\
\hline Household head age & $\begin{array}{l}-0.021 * * \\
{[0.010]}\end{array}$ & $\begin{array}{l}-0.005 \\
{[0.010]}\end{array}$ & $\begin{array}{l}-0.013 \\
{[0.009]}\end{array}$ & $\begin{array}{l}-0.007 \\
{[0.012]}\end{array}$ & $\begin{array}{l}-0.004 \\
{[0.007]}\end{array}$ \\
\hline $\begin{array}{l}\text { Household head experience in } \\
\text { farming }\end{array}$ & $\begin{array}{l}0.005 \\
{[0.007]}\end{array}$ & $\begin{array}{l}0.013 \\
{[0.009]}\end{array}$ & $\begin{array}{l}0.022 * * * \\
{[0.008]}\end{array}$ & $\begin{array}{l}0.011 \\
{[0.011]}\end{array}$ & $\begin{array}{l}0.017 * * \\
{[0.008]}\end{array}$ \\
\hline Number of plots & $\begin{array}{l}0.051 * * * \\
{[0.013]}\end{array}$ & $\begin{array}{l}0.031 * * \\
{[0.012]}\end{array}$ & $\begin{array}{l}0.043 * * * \\
{[0.012]}\end{array}$ & $\begin{array}{l}0.121 * * * \\
{[0.039]}\end{array}$ & $\begin{array}{l}0.036^{*} \\
{[0.020]}\end{array}$ \\
\hline Total plot area & $\begin{array}{l}-0.003 \\
{[0.031]} \\
\end{array}$ & $\begin{array}{l}0.024 \\
{[0.029]}\end{array}$ & $\begin{array}{l}0.010 \\
{[0.032]}\end{array}$ & $\begin{array}{l}0.072 \\
{[0.074]} \\
\end{array}$ & $\begin{array}{l}0.051 \\
{[0.036]} \\
\end{array}$ \\
\hline $\begin{array}{l}\text { Receiving non- agricultural } \\
\text { income }\end{array}$ & $\begin{array}{l}0.058 \\
{[0.203]}\end{array}$ & $\begin{array}{l}-0.116 \\
{[0.175]}\end{array}$ & $\begin{array}{l}-0.56 * * * \\
{[0.209]}\end{array}$ & $\begin{array}{l}0.351 \\
{[0.241]}\end{array}$ & $\begin{array}{l}-0.455^{* *} \\
{[0.189]}\end{array}$ \\
\hline $\begin{array}{l}\text { Household member receiving } \\
\text { some income from NREGA }\end{array}$ & $\begin{array}{l}-0.543 * * \\
{[0.228]}\end{array}$ & $\begin{array}{l}-0.52 * * * \\
{[0.167]}\end{array}$ & $\begin{array}{l}-0.069 \\
{[0.256]}\end{array}$ & $\begin{array}{r}-0.092 \\
{[0.534]}\end{array}$ & $\begin{array}{l}-0.056 \\
{[0.736]}\end{array}$ \\
\hline Dummy for clay soil & $\begin{array}{l}1.328 * * * \\
{[0.288]}\end{array}$ & $\begin{array}{l}0.752 \\
{[0.507]}\end{array}$ & $\begin{array}{l}-0.490 \\
{[0.537]}\end{array}$ & $\begin{array}{l}-0.092 \\
{[0.534]}\end{array}$ & $\begin{array}{l}-0.056 \\
{[0.736]}\end{array}$ \\
\hline Dummy for loamy soil & $\begin{array}{l}0.530 * \\
{[0.286]}\end{array}$ & $\begin{array}{l}0.346 \\
{[0.374]}\end{array}$ & $\begin{array}{l}0.213 \\
{[0.388]}\end{array}$ & $\begin{array}{l}0.303 \\
{[0.567]}\end{array}$ & $\begin{array}{l}-0.377 \\
{[0.395]}\end{array}$ \\
\hline Dummy for sandy soil & $\begin{array}{l}-0.012 \\
{[0.344]} \\
\end{array}$ & $\begin{array}{l}0.904 * \\
{[0.465]}\end{array}$ & $\begin{array}{l}-0.011 \\
{[0.498]}\end{array}$ & $\begin{array}{l}-0.343 \\
{[0.579]} \\
\end{array}$ & \begin{tabular}{|l|}
0.327 \\
{$[0.495]$} \\
\end{tabular} \\
\hline $\begin{array}{l}\text { Dummy scheduled caste }(=1 \\
\text { if yes, } 0 \text { if no) }\end{array}$ & $\begin{array}{l}-0.244 \\
{[0.274]}\end{array}$ & $\begin{array}{l}-0.285 \\
{[0.242]}\end{array}$ & $\begin{array}{l}-0.70 * * * \\
{[0.228]}\end{array}$ & $\begin{array}{l}0.190 \\
{[0.554]}\end{array}$ & $\begin{array}{l}0.075 \\
{[0.320]}\end{array}$ \\
\hline $\begin{array}{l}\text { Dummy scheduled tribe }(=1 \text { if } \\
\text { yes, } 0 \text { if no) }\end{array}$ & $\begin{array}{l}-0.641 * * \\
{[0.262]}\end{array}$ & $\begin{array}{l}-0.532 \\
{[0.577]}\end{array}$ & & $\begin{array}{l}-0.150 \\
{[0.700]}\end{array}$ & \\
\hline $\begin{array}{l}\text { Dummy other backward caste } \\
(=1 \text { if yes, } 0 \text { if no) }\end{array}$ & $\begin{array}{l}0.324^{*} \\
{[0.186]} \\
\end{array}$ & $\begin{array}{l}0.192 \\
{[0.187]}\end{array}$ & $\begin{array}{l}-0.069 \\
{[0.192]}\end{array}$ & $\begin{array}{l}0.335 \\
{[0.368]}\end{array}$ & $\begin{array}{l}0.209 \\
{[0.250]}\end{array}$ \\
\hline $\begin{array}{l}\text { Dummy minority (=1 if yes, } \\
0 \text { if no) }\end{array}$ & $\begin{array}{l}0.652 \\
{[0.450]} \\
\end{array}$ & $\begin{array}{l}0.270 \\
{[0.223]}\end{array}$ & $\begin{array}{l}-0.624 \\
{[0.420]}\end{array}$ & $\begin{array}{l}-0.049 \\
{[0.537]}\end{array}$ & $\begin{array}{l}0.020 \\
{[0.264]} \\
\end{array}$ \\
\hline $\begin{array}{l}\text { Dummy no schooling (=1 if } \\
\text { yes, }=0 \text { if no) }\end{array}$ & $\begin{array}{l}-1.047 * * \\
{[0.410]} \\
\end{array}$ & $\begin{array}{l}-0.525^{*} \\
{[0.309]}\end{array}$ & \begin{tabular}{|l|}
0.130 \\
{$[0.528]$} \\
\end{tabular} & $\begin{array}{l}-6.6^{* * * *} \\
{[0.64]} \\
\end{array}$ & $\begin{array}{l}-1.37 * * * \\
{[0.424]} \\
\end{array}$ \\
\hline $\begin{array}{l}\text { Dummy middle school }(=1 \text { if } \\
\text { yes, }=0 \text { if no) }\end{array}$ & $\begin{array}{l}-0.856^{* *} \\
{[0.415]}\end{array}$ & $\begin{array}{l}-0.496 * \\
{[0.276]}\end{array}$ & $\begin{array}{l}0.531 \\
{[0.632]}\end{array}$ & $\begin{array}{l}-6.67 * * * \\
{[0.654]}\end{array}$ & $\begin{array}{l}-1.24 * * * \\
{[0.458]}\end{array}$ \\
\hline $\begin{array}{l}\text { Dummy high school (=1 if } \\
\text { yes, }=0 \text { if no) }\end{array}$ & $\begin{array}{l}-0.724 \\
{[0.448]} \\
\end{array}$ & $\begin{array}{l}-0.500 \\
{[0.329]}\end{array}$ & $\begin{array}{l}0.194 \\
{[0.552]} \\
\end{array}$ & $\begin{array}{l}-6.38 * * * \\
{[0.67]}\end{array}$ & $\begin{array}{l}-1.207 * * \\
{[0.562]}\end{array}$ \\
\hline $\begin{array}{l}\text { Dummy intermediate degree } \\
(=1 \text { if yes, }=0 \text { if no })\end{array}$ & $\begin{array}{l}-0.743 \\
{[0.581]}\end{array}$ & $\begin{array}{l}-0.294 \\
{[0.265]}\end{array}$ & $\begin{array}{l}0.931 \\
{[0.728]}\end{array}$ & $\begin{array}{l}-6.76^{* * * *} \\
{[0.81]}\end{array}$ & $\begin{array}{l}-1.074^{*} \\
{[0.571]}\end{array}$ \\
\hline $\begin{array}{l}\text { Dummy for bachelor's degree } \\
(=1 \text { if yes, }=0 \text { if no })\end{array}$ & $\begin{array}{l}-0.614 \\
{[0.512]}\end{array}$ & $\begin{array}{l}0.237 \\
{[0.270]}\end{array}$ & $\begin{array}{l}1.139 * * \\
{[0.569]}\end{array}$ & $\begin{array}{l}-6.008 * * * \\
{[1.055]}\end{array}$ & $\begin{array}{l}-0.179 \\
{[0.371]}\end{array}$ \\
\hline $\begin{array}{l}\text { Dummy for information from } \\
\text { friend/neighbor }(1=\text { yes, } \\
=0 \text { if no) }\end{array}$ & $\begin{array}{l}0.352 * \\
{[0.192]}\end{array}$ & $\begin{array}{l}0.902 * * * \\
{[0.163]}\end{array}$ & $\begin{array}{l}1.075 * * * \\
{[0.161]}\end{array}$ & $\begin{array}{l}1.03 * * * \\
{[0.20]}\end{array}$ & $\begin{array}{l}1.134 * * * \\
{[0.174]}\end{array}$ \\
\hline $\begin{array}{l}\text { Dummy for information from } \\
\text { public extension (=1 if yes, } \\
=0 \text { if no) }\end{array}$ & $\begin{array}{l}0.393 \\
{[0.657]}\end{array}$ & $\begin{array}{l}0.951 * \\
{[0.507]}\end{array}$ & $\begin{array}{l}1.006 * * * \\
{[0.262]}\end{array}$ & $\begin{array}{l}1.306 \\
{[0.81]}\end{array}$ & $\begin{array}{l}1.100 * \\
{[0.601]}\end{array}$ \\
\hline
\end{tabular}


Table 18.7 (continued)

\begin{tabular}{l|l|l|l|l|l}
\hline & $\begin{array}{l}\text { Improved } \\
\text { variety }\end{array}$ & $\begin{array}{l}\text { Surface } \\
\text { seeding }\end{array}$ & $\begin{array}{l}\text { Zero } \\
\text { tillage } \\
\text { wheat }\end{array}$ & $\begin{array}{l}\text { Tried } \\
\text { improved } \\
\text { variety }\end{array}$ & $\begin{array}{l}\text { Tried } \\
\text { surface } \\
\text { seeding }\end{array}$ \\
\hline $\begin{array}{l}\text { Dummy for information from } \\
\text { private extension (=1 if yes, } \\
=0 \text { if no) }\end{array}$ & $\begin{array}{l}0.680 \\
{[0.540]}\end{array}$ & $\begin{array}{l}0.896 \\
{[0.604]}\end{array}$ & & & 1.077 \\
{$[0.807]$}
\end{tabular}

Robust standard errors in parentheses $-* * * \mathrm{p}<0.01, * * \mathrm{p}<0.05,{ }^{*} \mathrm{p}<0.1$. All standard errors are clustered at the district level

adopters. Recall that as much as $61 \%$ of farmers in the marginal districts of Bihar have adopted hybrid rice, while this number is below $15 \%$ for SC/ST farmers in Bihar. Wheat and maize are less stratified in technology adoption along caste lines. Though not presented here, the case is similar for IPM in rice.

4. Furthermore, knowledge about complex technologies is ordered not only along lines of caste but also educational qualification. Awareness of SRI, for example, is significantly associated with high school or a higher degree.

5. In terms of information sources, importantly, the private sector comprising input dealers and other non-government sources, such as the media, generally have not played a significant role. The awareness of technologies in rice has come about through strong social ties and the public sector extension services. Interestingly, in many hybrid seeds, the scaling up of adoption has happened because of an active private sector. In the adoption of hybrid rice, the private sector extension has played a significant role. This is to be expected, since in hybrid seeds, the private sector is the dominant input supplier. Surprisingly, the private sector extension does not have a significant effect on the awareness or adoption of hybrid maize whereever strong social ties with friends and neighbors alone have significant association with a farmer's knowledge about the technology.

6. Relative to the benchmark location (the omitted category in the block dummies), there are significant differences across blocks. The positive significant dummy implies that these blocks have significantly greater likelihood of being aware of/adopting the technology. With regard to the respective technologies, these blocks are in some way more marginal than the benchmark blocks. The evidence in this regard provides a basis for prioritizing such blocks which have low awareness or adoption. At the same time, to achieve maximize adoption, the blocks with greater likelihood of awareness and subsequent adoption could be targeted.

Finally, we look at the downside of respective technologies in terms of farmers' perceptions and their association with adoption (or lack of it). Here, we look merely at association rather than a causal relationship between perceptions of the flip side in a technology and its adoption. The perceived downside of a technology could be strong enough to be associated with lack of adoption. On the other side, if some 
Table 18.8 Awareness and adoption of technologies in maize: marginal effects from probit regressions

\begin{tabular}{|c|c|c|c|c|c|c|}
\hline & Hybrid & Spacing & $\begin{array}{l}\text { Nutrient } \\
\text { management }\end{array}$ & $\begin{array}{l}\text { Tried } \\
\text { hybrid } \\
\text { maize }\end{array}$ & $\begin{array}{l}\text { Tried } \\
\text { spacing } \\
\text { maize }\end{array}$ & $\begin{array}{l}\text { Tried } \\
\text { nutrient } \\
\text { management } \\
\text { maize }\end{array}$ \\
\hline Household size & $\begin{array}{l}0.020 \\
{[0.014]}\end{array}$ & $\begin{array}{l}0.079 * \\
{[0.046]} \\
\end{array}$ & $\begin{array}{l}0.135^{*} \\
{[0.075]}\end{array}$ & $\begin{array}{l}0.038 \\
{[0.026]}\end{array}$ & $\begin{array}{l}0.044 \\
{[0.064]}\end{array}$ & $0.107[0.067]$ \\
\hline $\begin{array}{l}\text { Household } \\
\text { head age }\end{array}$ & $\begin{array}{l}-0.006 \\
{[0.011]}\end{array}$ & $\begin{array}{l}-0.040^{* * *} \\
{[0.017]}\end{array}$ & $\begin{array}{l}-0.004 \\
{[0.032]}\end{array}$ & $\begin{array}{l}-0.01 \\
{[0.013]}\end{array}$ & $\begin{array}{l}-0.038 \\
{[0.02]}\end{array}$ & $\begin{array}{l}-0.026 \\
{[0.028]}\end{array}$ \\
\hline $\begin{array}{l}\text { Household } \\
\text { head experi- } \\
\text { ence in farming }\end{array}$ & $\begin{array}{l}0.013 \\
{[0.009]}\end{array}$ & $\begin{array}{l}0.022 * \\
{[0.013]}\end{array}$ & $\begin{array}{l}-0.035 \\
{[0.038]}\end{array}$ & $\begin{array}{l}0.010 \\
{[0.01]}\end{array}$ & $\begin{array}{l}-0.022 \\
{[0.03]}\end{array}$ & $\begin{array}{l}-0.011 \\
{[0.03]}\end{array}$ \\
\hline $\begin{array}{l}\text { Number of } \\
\text { plots }\end{array}$ & $\begin{array}{l}0.014 \\
{[0.012]}\end{array}$ & $\begin{array}{l}0.059 * * * \\
{[0.016]}\end{array}$ & $\begin{array}{l}0.032 * \\
{[0.018]} \\
\end{array}$ & $\begin{array}{l}0.015 \\
{[0.01]}\end{array}$ & $\begin{array}{l}0.058 \\
{[0.03]}\end{array}$ & $\begin{array}{l}0.059 * * \\
{[0.02]}\end{array}$ \\
\hline Total plot area & $\begin{array}{l}0.037 \\
{[0.033]}\end{array}$ & $\begin{array}{l}-0.044 \\
{[0.042]}\end{array}$ & $\begin{array}{l}-0.120 * * \\
{[0.055]}\end{array}$ & $\begin{array}{l}0.04 * * \\
{[0.02]}\end{array}$ & $\begin{array}{l}0.12 \\
{[0.096]}\end{array}$ & $0.038[0.063]$ \\
\hline $\begin{array}{l}\text { Receiving non- } \\
\text { agricultural } \\
\text { income }\end{array}$ & $\begin{array}{l}-0.221 \\
{[0.146]}\end{array}$ & $\begin{array}{l}0.149 \\
{[0.229]}\end{array}$ & & $\begin{array}{l}-0.5 * * * \\
{[0.12]}\end{array}$ & & \\
\hline $\begin{array}{l}\text { Household } \\
\text { member } \\
\text { receiving some } \\
\text { income from } \\
\text { NREGA }\end{array}$ & $\begin{array}{l}-0.297 * \\
{[0.168]}\end{array}$ & $\begin{array}{l}0.422 \\
{[0.485]}\end{array}$ & $\begin{array}{l}1.452 \\
{[1.228]}\end{array}$ & $\begin{array}{l}-0.25 \\
{[0.378]}\end{array}$ & $\begin{array}{l}1.671^{*} \\
{[0.99]}\end{array}$ & $1.783[1.147]$ \\
\hline $\begin{array}{l}\text { Dummy for } \\
\text { clay soil }\end{array}$ & $\begin{array}{l}-0.631 \\
{[0.395]}\end{array}$ & & & $\begin{array}{l}-0.255 \\
{[0.67]}\end{array}$ & & \\
\hline $\begin{array}{l}\text { Dummy for } \\
\text { loamy soil }\end{array}$ & \begin{tabular}{|l|}
-0.131 \\
{$[0.257]$} \\
\end{tabular} & $\begin{array}{l}-0.498 \\
{[0.570]} \\
\end{array}$ & $\begin{array}{l}5.031 * * * \\
{[1.272]}\end{array}$ & $\begin{array}{l}0.481 \\
{[0.343]}\end{array}$ & $\begin{array}{l}5.36^{* * * *} \\
{[0.9]} \\
\end{array}$ & $\begin{array}{l}5.30^{* * * *} \\
{[0.97]}\end{array}$ \\
\hline $\begin{array}{l}\text { Dummy for } \\
\text { sandy soil }\end{array}$ & $\begin{array}{l}-0.141 \\
{[0.254]}\end{array}$ & $\begin{array}{l}-0.195 \\
{[0.644]}\end{array}$ & $\begin{array}{l}4.348 * * \\
{[1.908]} \\
\end{array}$ & $\begin{array}{l}0.676 \\
{[0.420]}\end{array}$ & 5.302[.] & $4.342[]$. \\
\hline $\begin{array}{l}\text { Dummy sched- } \\
\text { uled caste }(=1 \\
\text { if yes, } 0 \text { if no) }\end{array}$ & $\begin{array}{l}-0.352 \\
{[0.288]}\end{array}$ & $\begin{array}{l}-0.398 \\
{[0.691]}\end{array}$ & & $\begin{array}{l}-0.34^{*} \\
{[0.20]}\end{array}$ & & \\
\hline $\begin{array}{l}\text { Dummy sched- } \\
\text { uled tribe }(=1 \\
\text { if yes, } 0 \text { if no) }\end{array}$ & $\begin{array}{l}0.152 \\
{[0.544]}\end{array}$ & & & $\begin{array}{l}0.432 \\
{[1.206]}\end{array}$ & & \\
\hline $\begin{array}{l}\text { Dummy other } \\
\text { backward caste } \\
\text { ( }=1 \text { if yes, } 0 \text { if } \\
\text { no) }\end{array}$ & $\begin{array}{l}0.045 \\
{[0.215]}\end{array}$ & $\begin{array}{l}-0.369 \\
{[0.316]}\end{array}$ & $\begin{array}{l}-1.084 \\
{[0.794]}\end{array}$ & $\begin{array}{l}0.170 \\
{[0.258]}\end{array}$ & $\begin{array}{l}-1.86^{* * * *} \\
{[0.6]}\end{array}$ & $\begin{array}{l}-1.244 \\
{[0.763]}\end{array}$ \\
\hline $\begin{array}{l}\text { Dummy minor- } \\
\text { ity (=1 if yes, } \\
0 \text { if no) }\end{array}$ & $\begin{array}{l}0.700^{* *} \\
{[0.315]}\end{array}$ & $\begin{array}{l}-0.299 \\
{[0.885]}\end{array}$ & $\begin{array}{l}-0.927 \\
{[1.339]}\end{array}$ & $\begin{array}{l}0.71 * * \\
{[0.36]}\end{array}$ & $\begin{array}{l}-1.18 \\
{[1.43]}\end{array}$ & $\begin{array}{l}-0.908 \\
{[1.416]}\end{array}$ \\
\hline $\begin{array}{l}\text { Dummy no } \\
\text { schooling ( }=1 \\
\text { if yes, }=0 \text { if no) }\end{array}$ & $\begin{array}{l}-0.179 \\
{[0.281]}\end{array}$ & $\begin{array}{l}-0.140 \\
{[0.415]}\end{array}$ & $\begin{array}{l}0.868 \\
{[0.795]}\end{array}$ & $\begin{array}{l}0.294 \\
{[0.420]}\end{array}$ & $\begin{array}{l}1.71^{*} \\
{[0.99]}\end{array}$ & $0.978[0.826]$ \\
\hline $\begin{array}{l}\text { Dummy mid- } \\
\text { dle school }(=1 \\
\text { if yes, }=0 \text { if no) }\end{array}$ & $\begin{array}{l}0.16 \\
{[0.342]}\end{array}$ & $\begin{array}{l}-0.538 \\
{[0.492]}\end{array}$ & $\begin{array}{l}-0.379 \\
{[0.748]}\end{array}$ & $\begin{array}{l}0.108 \\
{[0.416]}\end{array}$ & $\begin{array}{l}-0.009 \\
{[0.95]}\end{array}$ & $\begin{array}{l}-0.963 \\
{[0.911]}\end{array}$ \\
\hline
\end{tabular}


Table 18.8 (continued)

\begin{tabular}{|c|c|c|c|c|c|c|}
\hline & Hybrid & Spacing & $\begin{array}{l}\text { Nutrient } \\
\text { management }\end{array}$ & $\begin{array}{l}\text { Tried } \\
\text { hybrid } \\
\text { maize }\end{array}$ & $\begin{array}{l}\text { Tried } \\
\text { spacing } \\
\text { maize }\end{array}$ & $\begin{array}{l}\text { Tried } \\
\text { nutrient } \\
\text { management } \\
\text { maize }\end{array}$ \\
\hline $\begin{array}{l}\text { Dummy high } \\
\text { school ( }=1 \text { if } \\
\text { yes, }=0 \text { if no) }\end{array}$ & $\begin{array}{l}0.164 \\
{[0.335]}\end{array}$ & $\begin{array}{l}-0.657^{*} \\
{[0.377]}\end{array}$ & $\begin{array}{l}-0.715 \\
{[0.885]}\end{array}$ & $\begin{array}{l}0.073 \\
{[0.599]}\end{array}$ & $\begin{array}{l}-0.017 \\
{[0.61]}\end{array}$ & $\begin{array}{l}-0.424 \\
{[0.587]}\end{array}$ \\
\hline $\begin{array}{l}\text { Dummy inter- } \\
\text { mediate degree } \\
(=1 \text { if yes, } \\
=0 \text { if no })\end{array}$ & $\begin{array}{l}0.322 \\
{[0.403]}\end{array}$ & $\begin{array}{l}-1.379 * * \\
{[0.653]}\end{array}$ & & $\begin{array}{l}0.492 \\
{[0.460]}\end{array}$ & & \\
\hline $\begin{array}{l}\text { Dummy for } \\
\text { bachelor's } \\
\text { degree ( }=1 \text { if } \\
\text { yes, }=0 \text { if no) }\end{array}$ & $\begin{array}{l}0.329 \\
{[0.306]}\end{array}$ & $\begin{array}{l}-0.810 \\
{[0.604]}\end{array}$ & $\begin{array}{l}0.838 \\
{[1.135]}\end{array}$ & $\begin{array}{l}0.250 \\
{[0.466]}\end{array}$ & $\begin{array}{l}2.598 \\
{[1.641]}\end{array}$ & $0.782[1.321]$ \\
\hline $\begin{array}{l}\text { Dummy for } \\
\text { information } \\
\text { from friend/ } \\
\text { neighbor } \\
(1=\text { yes, }=0 \text { if } \\
\text { no })\end{array}$ & $\begin{array}{l}0.383 * * \\
{[0.151]}\end{array}$ & $\begin{array}{l}-0.306 \\
{[0.352]}\end{array}$ & $\begin{array}{l}0.057 \\
{[0.562]}\end{array}$ & $\begin{array}{l}0.119 \\
{[0.158]}\end{array}$ & $\begin{array}{l}-0.636 \\
{[0.65]}\end{array}$ & $\begin{array}{l}-0.376 \\
{[0.603]}\end{array}$ \\
\hline $\begin{array}{l}\text { Dummy for } \\
\text { information } \\
\text { from public } \\
\text { extension ( }=1 \\
\text { if yes, } 0 \text { if no) }\end{array}$ & $\begin{array}{l}0.880^{*} \\
{[0.459]}\end{array}$ & $\begin{array}{l}0.657 \\
{[0.736]}\end{array}$ & $\begin{array}{l}1.062 \\
{[1.020]}\end{array}$ & $\begin{array}{l}-0.595 \\
{[0.42]}\end{array}$ & $\begin{array}{l}-0.347 \\
{[1.15]}\end{array}$ & $0.371[1.012]$ \\
\hline \multicolumn{7}{|l|}{$\begin{array}{l}\text { Dummy for } \\
\text { information } \\
\text { from private } \\
\text { extension ( }=1 \\
\text { if yes, }=0 \text { if no) }\end{array}$} \\
\hline $\begin{array}{l}\text { Block fixed } \\
\text { effects }\end{array}$ & Yes & Yes & Yes & Yes & Yes & Yes \\
\hline Observations & 515 & 305 & 123 & 364 & 108 & 123 \\
\hline
\end{tabular}

perceived constraints are also significantly associated with adoption, it would imply that the scale of adoption could be higher if those downsides of the technology were addressed.

The downside of technologies could be among the perceived constraints in adoption; in IPM, the farmers who see this as a new technology that would force them to engage in experimentation are less likely to adopt this technology. In hybrid rice, the propensity to adopt is associated with perceptions of high costs and lack of marketing opportunities for the product. Those who see downside risk in hybrid rice 
are significantly less likely to be adopters of hybrid rice. In mechanized DSR, lack of adoption is associated with information constraints, as well as a perception that the technology performs far below the potential.

Table 18.7 looks at the awareness and adoption of technologies in wheat. For illustration, we look at the case of two technologies, viz. surface seeding (SS) and improved varieties in wheat (IV). Again, the other backward caste turns out to be the group with greater awareness of technologies. It is also associated with greater adoption of technologies in wheat. As in the case of rice technologies, the greater number of plots the farmer has raises the likelihood of the farmer trying new technologies. Furthermore, importantly, the main providers of information regarding technologies in wheat in the marginal districts of the two states are the public extension services. Unlike other crops, such as cotton, pearl millet and maize, for which private sector seed have become widespread and sources such as input dealers have become important channels for information, the wheat case represents the case of low penetration of the private sector. Unless extension is provided as a bundled product with new technologies in wheat, systems would have to rely on public extension for introduction and spread of any new technology in wheat.

In surface seeding of rice, there are several downsides to the technology likely perceived by potential adopters. Perceptions of high input costs, high downside risk and observation of several failures of the technology are associated significantly with adoption. In wheat, both technologies are associated with information constraints, which is to be expected given the state of public extension, the primary source of information in wheat.

The analyses above point to technology-specific factors having a bearing on both awareness as well as adoption of specific technologies in different cases. In effect, each technology has different determining factors with regard to its awareness and uptake by farmers. There are three logical scenarios to consider: (i) Awareness of technology; (ii) Adoption conditional on awareness; and (iii) Non-adoption conditional on awareness. The factors explaining these three states definitely have significantly different implications. While lack of awareness mandates that information dissemination about the technology and its potential should be prioritized, lack of adoption upon awareness implies that suitability of the technology, including the need for complementary inputs, should be explored and resolved.

\section{Conclusions and Policy Recommendations}

In this paper, we conduct an ex ante assessment of technologies for crop-specific marginal districts in Bihar and Odisha. Relying on dynamic behaviour of yields and current performance for rice, wheat and maize, marginal districts in Bihar and Odisha were identified. With the yield behaviour so considered for the principal crops, the marginal districts map closely into alternative criteria that could be used to find said districts. 
Based on information from several sources, the potential of different technologies was gauged for the marginal districts. The findings from stakeholder elicitation was cross-validated with a primary survey in selected marginal districts in the two states. The survey results provide important information about crops/activities that farmers aspire to. Maize and pulses are two sectors in which there could be good payoff, as a number of farmers aspire to get into producing them.

In both states, there is generally a significant lack of awareness of agricultural technology, more so in marginal districts of Odisha. Some modern technologies, like hybrid rice in Bihar, have become quite well known to the farmers, while others, like Systems of Rice Intensification, in spite of having existed for quite some time, have not yet broken the information barriers. Awareness of technologies is also stratified along socio-economic lines. Smaller farmers and farmers belonging to the lowest caste fare badly, both in awareness as well as adoption of technologies.

Translation from awareness to adoption has been quite difficult for most technologies. In general, the technologies related to varietal adoption have been comparatively successful in this regard. In many others, as they get more complex and there is a greater need for complementary inputs, adoption of certain technologies, even in the presence of awareness, has been difficult.

Policies for technology promotion in the marginal districts have to take into account the current state, as well the aspirations, of the farmers. These aspirations relate both to the crops/activities that farmers want to engage in as well as different technologies that they want to adopt but cannot because of constraints. Given the evidence of the disconnect between awareness and execution, a holistic approach taking into account the whole process of adoption from information to support in adoption will be needed. The state of the farmers dealing with illiteracy, small land sizes and social barriers mandate a tailored approach in technology choice for the lagging districts in Bihar and Odisha.

Rationalization of technologies in the context of these districts needs to be done. A demand-pull approach that takes into account a farmer's preferences and his capacity should be adopted in introducing or promoting technologies. Several of the technologies that have been much publicized, such as SRI and Laser Land Levelling, only had limited success because underlying conditions did not support the comprehensive spread of the technology.

Some technologies clearly stand out for the marginal districts and could be promoted. These constitute hybrid rice, varietal improvement in wheat, and organic/semi-organic farming, all of which exhibit high potential. On the crop front, maize and pulse technology should be made more focal in policy.

Open Access This chapter is distributed under the terms of the Creative Commons AttributionNoncommercial 2.5 License (http://creativecommons.org/licenses/by-nc/2.5/) which permits any noncommercial use, distribution, and reproduction in any medium, provided the original author(s) and source are credited.

The images or other third party material in this chapter are included in the work's Creative Commons license, unless indicated otherwise in the credit line; if such material is not included in the work's Creative Commons license and the respective action is not permitted by statutory regulation, users will need to obtain permission from the license holder to duplicate, adapt or reproduce the material. 


\section{References}

Banerjee G, Palke LM (2010) Economics of pulses production and processing in India. Occasional Paper number 51. Department of Economic Analysis and Research, National Bank for Agriculture and Rural Development (NABARD), Mumbai

Bhadauria JS (2013) Impact of caste in adoption of technology in rural India. Agric Update 8 (3):386-388

Birner R, Anderson J (2007) How to make agricultural extension demand driven? The case of India's agricultural extension policy, Discussion paper no 00729. International Food Policy Research Institute, Washington, DC

Chowdhary VM, Vinu Chandran R, Neeti N, Bothale RV, Srivastava YK, Ingle P, Ramakrishnan D, Dutta D, Jeyaram A, Sharma JR, Singh R (2008) Assessment of surface and sub-surface waterlogged areas in irrigation command areas of Bihar state using remote sensing and GIS. Agric Water Manag 95:754-766

Foster AD, Rosenzweig MR (2010) Microeconomics of technology adoption. Annu Rev Econ 2(1):395-424, 09

Ghatak M, Roy S (2007) Land reform and agricultural productivity in India. A review of evidence. Oxford Rev Econ Policy 23(2):251-269

Government of India (2008) Road map for rural industrialization in Bihar. A report of the special task force on Bihar. Government of India, New Delhi

Kumar SM (2013) Does access to formal agricultural credit depend on caste? World Dev 43:315-328

Lybbert TJ, Magnan N, Bhargava AK, Gulati K, Spielman DJ (2013) Farmers' heterogeneous valuation of laser land leveling in Eastern Uttar Pradesh: an experimental auction to inform segmentation and subsidy strategies. Am J Agric Econ 95(2):339-345

MHA (2011) Census of India. Ministry of Home Affairs, Government of India, New Delhi

Pathak H, Tewari AN, Sankhyan S, Dubey DS, Mina U, Singh VK, Jain N, Bhatia A (2011) Directseeded rice: potential, performance and problems - a review. Curr Adv Agric Sci 3(2):77-88

Planning Commission (2013) Press note on poverty estimates, 2011-12. Government of India Planning Commission, New Delhi

Pomp M, Burger K (1995) Innovation and imitation: adoption of cocoa by Indonesian smallholders. World Dev 23(3):423-431

Prasad CS (2006) System of rice intensification in India. Innovation history and institutional challenges. WWF Project 'Dialogue on water, Food and Environment' c/o ICRISAT, Patancheru

Reddy JN, Sarkar RK, Patnaik SSC, Singh DP, Singh US, Ismail AM, Mackill DJ (2009) Improvement of rice germplasm for rainfed lowlands of eastern India. SABRAO J Breed Genet 41, Special Supplement

Singh KK, Ali M, Venkatesh MS (2009) Pulses in cropping systems. Technical Bulletin IIPR, Kanpur

Srinivasarao C, Sreenath D, Srinivas I, Sanjeeva Reddy B, Adake RV, Shailesh B (2013) Operationalization of custom hiring centres on farm implements in hundred villages in India. Central Research Institute for Dryland Agriculture, Hyderabad, p 151

Yamano T, Rajendran S, Malabayabas M (2013) Psychological constructs toward agricultural technology adoption: evidence from Eastern India. Contributed paper at the 87th annual conference of the agricultural economics society, University of Warwick, Coventry, 8-10 Apr 